\title{
CARBON EMISSIONS AND SEQUESTRATION IN FORESTS: CASE STUDIES FROM SEVEN DEVELOPING COUNTRIES
}

\author{
LBL- -32759 \\ VOLUME 3: INDIA AND CHINA \\ DE93 001600
}

N.H. Ravindranath, B.S. Somashekhar, and M. Gadgil

Center for Ecological Sciences and ASTRA

Indian Institute of Science

Bangalore, India

\author{
Xu Deying \\ Research Institute of Forestry \\ Chinese Academy of Forestry \\ Beijing, China
}

\section{Series Editors: Willy Makundi and Jayant Sathaye \\ Energy and Environment Division \\ Energy Analysis Program \\ Lawrence Berkeley Laboratory}

August 1992

\section{DRAFT}

Climate Change Division

Environmental Protection Agency

Washington, DC, USA
Energy and Environment Division Lawrence Berkeley Laboratory Berkeley, CA, USA

This work was supported by the U.S. Environmental Protection Agency, Office of Policy Analysis, Climate Change Division, through the U.S. Department of Energy under Contract No. DE-AC03-76SF00098. 


\title{
TABLE OF CONTENTS
}

PART 1: INDIA

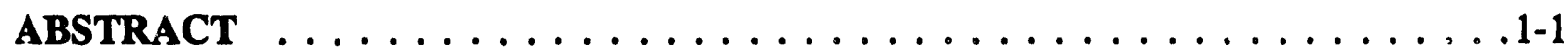

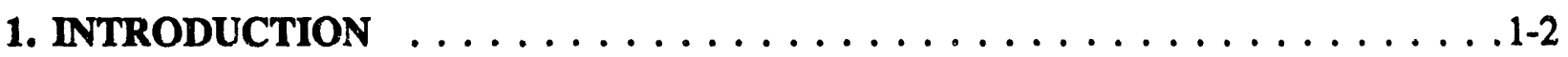

2. LAND-USE PATTERNS IN INDIA $\ldots \ldots \ldots \ldots \ldots \ldots \ldots \ldots \ldots \ldots$

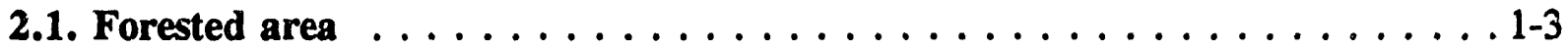

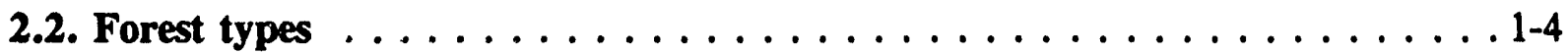

2.3. Deforested area . . . . . . . . . . . . . . . . . . . . 1-4

2.4. Conversion of deforested area to other land uses. . . . . . . . . . 1-7

3. BIOMASS DEMANDS ON INDIAN FORESTS $\ldots \ldots \ldots \ldots \ldots \ldots \ldots \ldots$

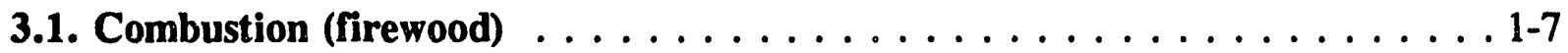

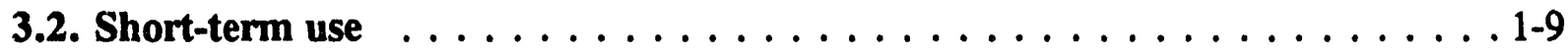

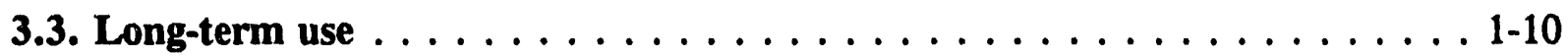

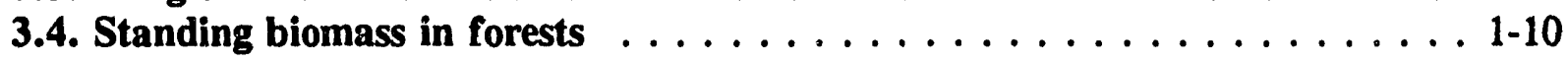

4. HISTORICAL AND CURRENT TRENDS IN CARBON FLUX $\ldots \ldots \ldots \ldots \ldots$. $\ldots \ldots$

4.1. Carbon storage . . . . . . . . . . . . . . . . 1-10

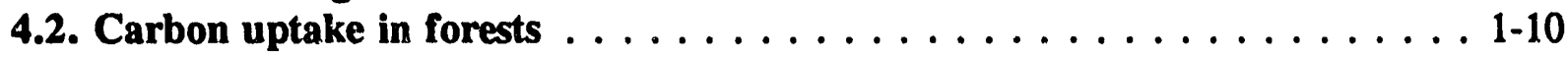

4.3. Carbon emissions . . . . . . . . . . . . . . . . . . . . 1-13

4.3.1. Carbon emissions from clear-felled forests . . . . . . . . . . 1-13

4.3.2. Carbon emissions from current year's production . . . . . . . . 1-15

4.3.3. Carbon emissions from degradation and illegal removal . . . . . . 1-15

4.3.4. Carbon emissions from shifting cultivation $\ldots \ldots \ldots \ldots \ldots \ldots$ 1-15

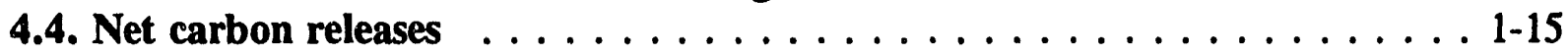

4.5. Explanation for no net carbon releases $\ldots \ldots \ldots \ldots \ldots \ldots \ldots \ldots$

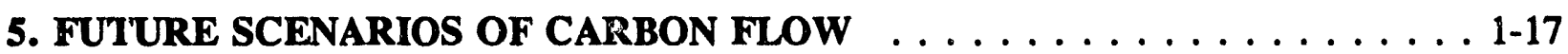

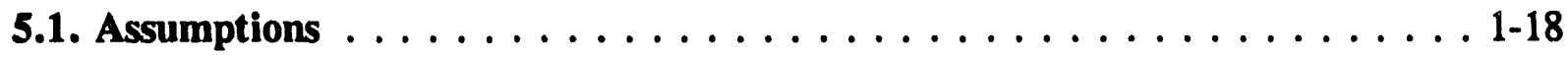

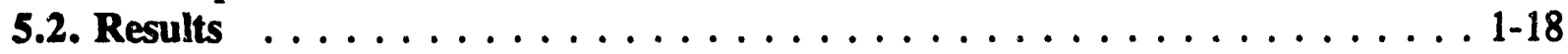

6. CONCLUSION: FORESTRY FOR GLOBAL AND LOCAL BENEFITS $\ldots \ldots$ 1-19

APPENDIX I: SOURCES OF FIREWOOD $\ldots \ldots \ldots \ldots \ldots \ldots \ldots \ldots \ldots$ 1-21

APPENDIX II: MAXIMUM STANDING BIOMASS OF DIFFERENT FOREST

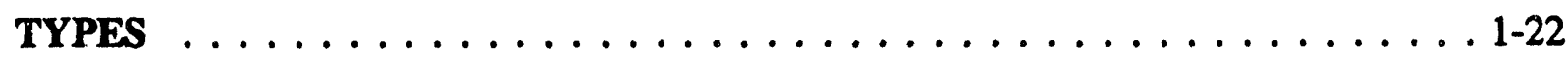

APPENDIX III: SOIL CARBON IN DIFFERENT FOREST TYPES . . . . . . 1-23 
APPENDIX IV: NET PRIMARY PRODUCTIVITY . . . . . . . . . . . . . . . 1-24

APPENDIX V: REFERENCES TO APPENDICES I-IV . . . . . . . . . . . 1-26

REFERENCES . . . . . . . . . . . . . . . . . . . . . 1-29

PART 2: CHINA

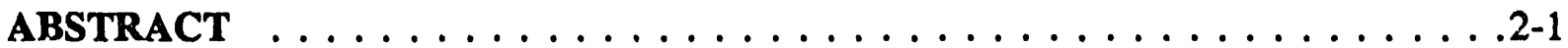

1. INTRODUCTION $\ldots \ldots \ldots \ldots \ldots \ldots \ldots \ldots \ldots \ldots \ldots \ldots \ldots \ldots \ldots \ldots \ldots .2$

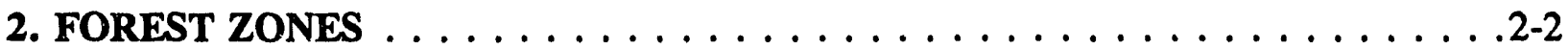

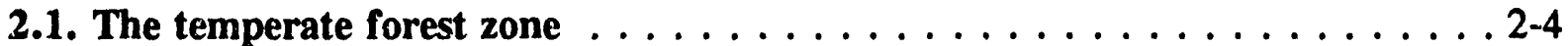

2.2. The west sub-zone of the subtropical forest $\ldots \ldots \ldots \ldots \ldots \ldots \ldots \ldots$

2.3. The east sub-zone of the subtropical forest $\ldots \ldots \ldots \ldots \ldots \ldots \ldots 2-4$

2.4. The warm temperate forest zone . . . . . . . . . . . . . . 2-4

2.5. The Xishuangbanna tropical pre-montane moist forest zone $\ldots \ldots \ldots 2-5$

2.6. The Hainan tropical pre-montane moist forest zone . . . . . . . . . 2-5

3. OWNERSHIP AND UTILIZATION OF FORESTS $\ldots \ldots \ldots \ldots \ldots \ldots$ 2-5

4. REFORESTATION AND AFFORESTATION $\ldots \ldots \ldots \ldots \ldots \ldots \ldots$ 2-7

5. MODEL AND PARAMETERS $\ldots \ldots \ldots \ldots \ldots \ldots \ldots \ldots \ldots$. . . . . . . . . . . . .

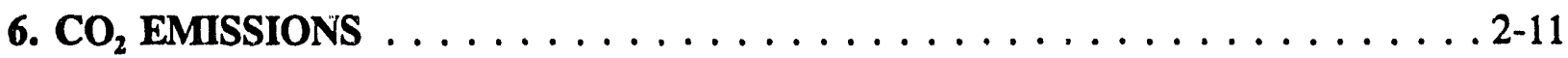

7. ECONOMIC ASPECTS $\ldots \ldots \ldots \ldots \ldots \ldots \ldots \ldots \ldots \ldots \ldots \ldots \ldots \ldots \ldots$ 2-15

8. DISCUSSION AND FUTURE RESEARCH $\ldots \ldots \ldots \ldots \ldots \ldots \ldots$ 2-15

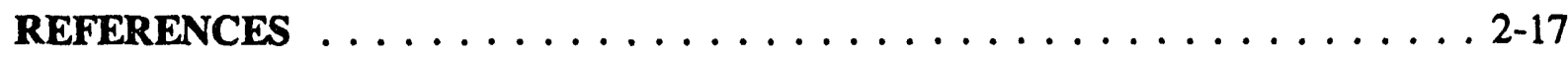




\section{PREFACE}

In January 1990, scientists and policymakers from around the world convened for a meeting of the Intergovernmental Panel on Climate Change (IPCC) in São Paulo, Brazil, to continue the ongoing discussions on emissions of greenhouse gases and global climate change. As part of the effort to further understand the sources of carbon dioxide $\left(\mathrm{CO}_{2}\right)$ and other major greenhouse gases, LBL and the University of Sao Paulo, with support from the U.S. Environmental Protection Agency, organized a workshop on tropical forestry and global climate change which was attended by the IPCC conference participants. Discussions at the workshop led to the establishment of the Tropical Forestry and Global Climate Change Research Network (F-7). The countries taking part in the F-7 Network -- Brazil, China, India, Indonesia, Malaysia, Mexico, Nigeria and Thailand -- possess among the largest tracts of the Earth's tropical forests and together experience the bulk of tropical deforestation.

The following research objectives were identified as the F-7 Network's priorities:

1. To improve and expand the body of knowledge about the extent of tropical deforestation through the use of available tools, including remote-sensing imagery, detailed biomass measurements and existing models.

2. To explore the dynamics of forest land use within the context of individual country's social and economic structures.

3. To identify alternative response options aimed at stemming deforestation and promoting sustainable land-use practices while maintaining each country's economic well-being. Meeting this objective includes carrying out an assessment of the economic costs of implementing various mitigative policies.

One of the strategies of this project was to rely on the work of indigenous researchers and institutions from each of the participating countries. This approach allowed for the integration of more precise, on-site information, some of which had not been previously published, into the more general and universally available base of knowledge. The Lawrence Berkeley Laboratory (LBL), which employed a similar approach to carry out a study on carbon emissions from energy use in developing countries (LDCs) (see Sathaye and Ketoff 1991), coordinated the work of the researchers and provided scientific and institutional support for the F-7 participants. The U.S. Environmental Protection Agency (EPA) financed the Network's work.

The information contained in this report represents the results of the first phase of the F-7 project, which had the explicit aim of providing quantitative data on forestry-related carbon emissions in the F-7 countries. This report contains the results of the first phase of the research effort. The next stage of the process will involve an assessment of response options in the forestry sector and the economics of undertaking these measures. 
The following scientists and institutions participated in the research:

\begin{tabular}{|c|c|c|}
\hline Country & Expert & Institution \\
\hline Brazil & Philip Fearnside & $\begin{array}{l}\text { Departmento de Ecologia } \\
\text { Instituto Nacional de Pesquisas de Amazonia } \\
\text { Manaus-Amazonia }\end{array}$ \\
\hline China & Xu Deying & $\begin{array}{l}\text { Research Institute of Forestry } \\
\text { Chinese Academy of Forestry } \\
\text { Beijing }\end{array}$ \\
\hline India & $\begin{array}{l}\text { N.H. Ravindranath } \\
\text { B.S. Somashekhar } \\
\text { Madhav Gadgil }\end{array}$ & $\begin{array}{l}\text { Centre for Ecological Sciences } \\
\text { Indian Institute of Science } \\
\text { Bangalore }\end{array}$ \\
\hline Indonesia & Edy Brotoisworo & $\begin{array}{l}\text { Institute of Ecology } \\
\text { Padjadjaran University } \\
\text { Bandung }\end{array}$ \\
\hline Malaysia & $\begin{array}{l}\text { Roslan Ismail } \\
\text { Ismariah Ahmad } \\
\text { Faizah Fakhruddin }\end{array}$ & $\begin{array}{l}\text { Forest Research Institute } \\
\text { Kepong } \\
\text { Kuala Lumpur }\end{array}$ \\
\hline Mexico & $\begin{array}{l}\text { Omar Masera Cerutti } \\
\text { María de Jesús Ordóñez } \\
\text { Rodolfo Dirzo Minjarez }\end{array}$ & $\begin{array}{l}\text { Centro de Ecología } \\
\text { Universidad Nacional Autonoma de México } \\
\text { Mexico City }\end{array}$ \\
\hline Thailand & $\begin{array}{l}\text { Somthawin Patanavanich } \\
\text { Ladawan Atipanumpai }\end{array}$ & $\begin{array}{l}\text { Thailand Development Research Institute } \\
\text { Faculty of Forestry, Kasetsart University } \\
\text { Bangkok }\end{array}$ \\
\hline USA & $\begin{array}{l}\text { Willy Makundi } \\
\text { Jayant Sathaye }\end{array}$ & $\begin{array}{l}\text { Energy and Environment Division } \\
\text { Lawrence Berkeley Laboratory }\end{array}$ \\
\hline
\end{tabular}

The opinions expressed in this work are those of the authors and do not necessarily reflect those of the affiliated institutions or of the respective governments.

An international workshop to discuss the methods, results and policy issues associated with this project was held at the Lawrence Berkeley Laboratory in May 1991. We would like to thank the workshop participants and extend a special acknowledgement to Ken Andrasko of the U.S. EPA for his contribution. A full list of the workshop participants is provided in the appendix. The authors would also like to thank Nina Goldman for editing this work. 
PART 1: INDIA

\title{
CARBON FLOWS IN INDIAN FORESTS
}

\author{
N.H. Ravindranath, B.S. Somashekhar and \\ Madhav Gadgil
}

Centre for Ecological Sciences and ASTRA Indian Institute of Science

Bangalore 560012 INDIA

August 1992 


\begin{abstract}
India's forests play a vital role in the global carbon cycle and make numerous contributions to the country's economic and environmental well-being. The forests offer an opportunity for sequestering carbon dioxide emitted from various anthropogenic activities. To date, however, little progress has been made towards quantifying the carbon emissions associated with the use of forests in India. This study attempts to estimate the carbon emissions and seqestration in these forests. Drawing from a series of satellite images from the 1980 s and other recent research, this paper provides a detailed overview of India's forest sector, including the classification of forest lands, as well as extent, rates and causes of deforestation for the base year. Based on the above and other available data, this paper provides estimates of carbon storage, uptake and emissions in Indian forests for 1986 and presents two possible visions of emission profile in the year 2011. The study finds that while Indian forests generated about 64 million tonnes of carbon in the base year, the corresponding uptake from growing forests (plantations and secondary forests) was estimated at 69 million tonnes. The business-as-usual projection for 2011 forecasts that forestry emissions will increase by 56 percent over the 1986 level. The more optimistic picture of 2011 limits the increase in emissions to 10 percent of the base year value. The more favorable of the two long-term scenarios would increase carbon uptake threefold between 1986 and 2011 through the implementation of a series of measures which offer local, national and global benefits.
\end{abstract}




\section{INTRODUCTION}

Deforestation in the tropics has contributed to the rise in atmospheric concentration of carbon dioxide $\left(\mathrm{CO}_{2}\right)$. On the other hand, carbon sequestration by growing forests has been shown to bea cost-effective option for mitigating global climatic change (Andrasko 1990). In addition, bioenergy culled from forests and tree plantations can provide a renewable energy source to replace fossil fuels (Hall et al. 1991). Thus, developing a sustainable reliance on forest resources can help to avert the build up of greenhouse gases associated with the intensive use of oil, coal and other carbon-intensive energy sources. In developing countries like India, forests are important for a variety of other reasons, including: conserving biological diversity, sustiinence of watersheds and meeting the diverse biomass needs of local communities.

There may not be any conflict regarding the role of forestry in achieving global, national and local objectives. In the context of global warming there is a need to clearly understand the contribution of the forestry sector to emissions of greenhouse gases, particularly $\mathrm{CO}_{2}$, and to evaluate its potential role in coping with global warming. Several recent studies have attempted to estimate global carbon emissions from forests (Houghton 1991; Hao et al. 1990; Myers 1989), and the estimated annual carbon release lies between 1.5 - 3.6 gigatonnes of carbon (GtC). These uncertainties result from the difficulties associated with obtaining accurate data on rates of deforestation, the modes and purpose of forest conversion, the extent of forest degradation, carbon content in both standing biomass and soil in different forest types, the rate at which the carbon is released into the atmosphere and the extent and rate of rea-absorption by growing vegetation.

As the climate change debate advances, policy makers require more accurate information on emissions and sequestration in the forestry sector. For this reason, there is a need to study the carbon flow in forests at the country level as a necessary step in arriving at more reliable global estimates. This study aims at understanding the carbon flow in Indian forests and at evaluating their contribution to the atmospheric $\mathrm{CO}_{2}$ build-up. It will also attempt to identify the factors that influence the carbon flow and to consider some policy options which can be implemented in the forestry sector for both local and global benefits. Specifically, the study aims at addressing the following:

1. To identify the area under different forest types and estimate both the standing and detrital biomass, and the total carbon storage in each forest type.

2. To estimate the extent and rate of deforestation and forest degradation, and to understand the local population's dependence on forests for meeting various biomass needs. This information will facilitate estimates of the levels of carbon release associated with various conversions;

3. To estimate the net carbon emissions from the forestry sector; 
6. To analyze some forestry strategies for promoting benefits to the environment and local communities.

The methodology is mainly based on the COPATH model developed by Makundi et al. (1991). However, several additions and modifications are incorporated into the model so as to be able to handle aspects unique to Indian forestry. Carbon flows in the Indian forest sector were estimated for the 1986 reference year.

\section{LAND-USE PATTERNS IN INDIA}

India, with a population of 843 million, has a geographic area of 328.8 million hectares (ha). As shown in Table 1 below, nearly half of the land area is under agricultural crops. Forests account for 22.8 percent of the land area. The share under various categories of use other than forests and crop lands account for 15.3 percent, or 50.3 million ha, of the total land area (Table 1). Most of this land is highly degraded and has a poor vegetation cover. About 15 percent of the land area is either barren and wasteland or is unclassified in terms of land use.

Table 1. Land-use patterns in India

\begin{tabular}{lcc}
\hline \hline Land Use & $\begin{array}{c}\text { Area } \\
\left(10^{6} \mathrm{ha}\right)\end{array}$ & $\begin{array}{c}\text { percent of } \\
\text { total area }\end{array}$ \\
\hline \hline Agriculture/area cropped & 154.70 & 47.0 \\
$\begin{array}{l}\text { Forests } \\
\text { (area officially recorded as forests) }\end{array}$ & 75.18 & 22.9 \\
$\begin{array}{l}\text { Permanent pastures and other grazing } \\
\text { land }\end{array}$ & 12.15 & 3.7 \\
$\begin{array}{l}\text { Land under cultivable tree crop and } \\
\text { groves }\end{array}$ & 3.91 & 1.2 \\
Cultivable wasteland & 16.64 & 5.1 \\
Land under other non-agricultural uses & 17.53 & 5.3 \\
Barren and wasteland & 24.60 & 7.5 \\
Area for which no records exist & 24.09 & 7.3 \\
\hline \hline Total & 328.80 & 100.0 \\
\hline \hline
\end{tabular}

Source: Ministry of Environment and Forests, 1987

\subsection{Forested area}

Estimates of forested area in India have been highly contested in the past. However, with access to satellite imagery data, current estimates appear more certain (Table 2) (Ministry of

$$
1-3
$$


Table 2. Area under forests statewide (1981-83 and 1985-87) in $10^{3} \mathrm{ha}$.

\begin{tabular}{|c|c|c|c|c|c|}
\hline $\begin{array}{c}\text { Statel } \\
\text { Union territories }\end{array}$ & $\begin{array}{l}1987 \text { Assessment } \\
\text { besed on imagery } \\
1981-83\end{array}$ & $\begin{array}{l}1989 \text { Assessment } \\
\text { based on imagery } \\
1985-87\end{array}$ & $\begin{array}{l}1989 \text { Assessment } \\
\text { Dense forest (Crown } \\
\text { cover above 40\%) }\end{array}$ & $\begin{array}{l}1989 \text { Ascessment } \\
\text { Open forest (Crown } \\
\text { cover 10\% to 40\%) }\end{array}$ & $\begin{array}{l}\text { Mean net area } \\
\text { deforested per } \\
\text { year, 1982-86 }\end{array}$ \\
\hline Andhra Pradesh & 5019.4 & 4791.1 & 2553.5 & 2197.1 & 57.075 \\
\hline Arumachal Pradesh & 6050.0 & 6876.3 & 5427.2 & 1449.1 & - \\
\hline Acan & 2638.5 & 2605.8 & 1668.8 & 937.0 & 8.200 \\
\hline Bihar & 2874.8 & 2693.4 & 1341.2 & 1352.2 & 45.350 \\
\hline Gou (including Daman \& Diu) & 128.5 & 130.0 & 97.5 & 32.2 & - \\
\hline Gujant & 1357.0 & 1167.0 & 525.9 & 599.9 & 47.500 \\
\hline Haryane & 64.4 & 56.3 & 13.0 & 43.3 & 2.025 \\
\hline Hinachal Pradesh & 1288.2 & 1337.7 & 710.0 & 627.7 & - \\
\hline Jammu \& Kashmir & 2088.0 & 2042.4 & 1082.4 & 960.0 & 11.400 \\
\hline Karnataka & 3226.4 & 3210.0 & 2474.9 & 735.1 & 4.100 \\
\hline Kerala & 1040.0 & 1014.7 & 831.2 & 183.7 & 6.325 \\
\hline Madhya Pradesh & 12774.9 & 13319.1 & 9144.8 & 4174.3 & - \\
\hline Maharashtra & 4741.6 & 4405.8 & 2617.7 & 1776.7 & 83.950 \\
\hline Manipur & 1767.9 & 1788.5 & 506.0 & 1282.5 & - \\
\hline Meghalaya & 1651.1 & 1569.0 & 342.7 & 1226.3 & 20.525 \\
\hline Mizoram & 1909.2 & 1817.8 & 388.3 & 1429.5 & 22.850 \\
\hline Nagaland & 1435.1 & 1435.6 & 463.2 & 972.4 & - \\
\hline Orissa & 5316.3 & 4713.7 & 2756.1 & 1938.4 & 150.650 \\
\hline Punjab & 76.6 & 116.1 & 9.7 & 106.4 & - \\
\hline Rajasthan & 1247.8 & 1296.6 & 290.2 & 1006.4 & - \\
\hline Sikkim & 283.9 & 312.4 & 241.0 & 71.4 & - \\
\hline Tamilnadu & 1838.0 & 1771.5 & 975.9 & 790.9 & 16.625 \\
\hline Tripura & 574.3 & $532: 5$ & 121.4 & 411.1 & 10.450 \\
\hline Utuara Pradesh & 3144.3 & 3384.4 & 2263.2 & 1121.2 & - \\
\hline West Bengal & 881.1 & 839.4 & 333.2 & 295.3 & 10.425 \\
\hline Andaran \& Nicobar & 760.3 & 762.4 & 651.8 & 13.3 & 0.800 \\
\hline Other territories & 265.0 & 23.5 & 16.2 & 7.5 & - \\
\hline TOTAL & 64203.9 & 64013.0 & 37847.0 & 25740.9 & 498.250 \\
\hline
\end{tabular}

Source: Ministry of Environment and Forests, 1989. 
Environment and Forests 1990). ${ }^{1}$ According to a recent assessment (1985-87), 64.01 million ha, or 19.5 percent of India's geographic area, is under forests with over 10 percent crown cover. The total area under dense forest (with over 40 percent crown cover) is only 37.8 million ha, or 11.5 percent of India's geographic area. The forested area includes natural forests, forest plantations and plantation crops, like rubber and fruit trees. Forests and plantation areas with less than 10 percent crown cover do not fall under the definition of "forests" used in this study.

\subsection{Forest types}

Indian forests have been classified into four major groups based on climate and location (Ministry of Environment and Forests 1987): tropical forests; montane subtropical iorests; montane temperate forests; and alpine forests. Each of these major groups is further classified into different forest types based on vegetation type. The area under each forest type is given in Table 3. Tropical moist deciduous and tropical dry deciduous forests dominate, accounting for 36 and 28.2 percent of the total forest area respectively.

\subsection{Deforested area}

The most commonly quoted figure for the area deforested annually in India is 0.4 million ha (Myers 1989). It is not clear how this figure was estimated or whether it takes into account the area brought under afforestation each year. In this study we used satellite imagery taken at two different periods four years apart to provide estimates of the changes in the forested area (including the area brought under tree plantations) (Table 2). The total area under forests declined by 190,90 n na during the four-year period. Thus, the annual loss of forest area net of afforestation and reforestation is 47,725 ha as compared to the 0.4 million ha quoted in the literature (Myers, 1989). The year of reference for the estimates in this study is 1986, (the midyear of the 1985-87 imagery assessment). The following procedure was adopted for estimating the extent of the deforested area.

All the states where there was a decline in area under forest between the years 1982 and 1986 are considered. The net decline in forest area was estimated and then divided by four to obtain the mean annual area deforested in each state.

Net area deforested in a year $=$

$$
\sum_{i=1}^{27}\left(A 82_{i}-A 86_{i}\right) / 4
$$

Only for those states where A $82_{i}>$ A $86_{i}$. A $82_{i}=$ Area under forest in 1982 assessment in State " $i "$ A $86_{i}=$ Area under forest in 1986 assessment of State " $i "$ $\mathrm{i}=1$ to 27 states and union territories.

The sum of the area in all such states is considered as the net area deforested during the reference year 1986. The area brought under forest plantations is included as forest area.

\footnotetext{
The satellite assessment carried out during 1981-83 and 1985-87 was the basis for the estimates of changes in the forest area. 


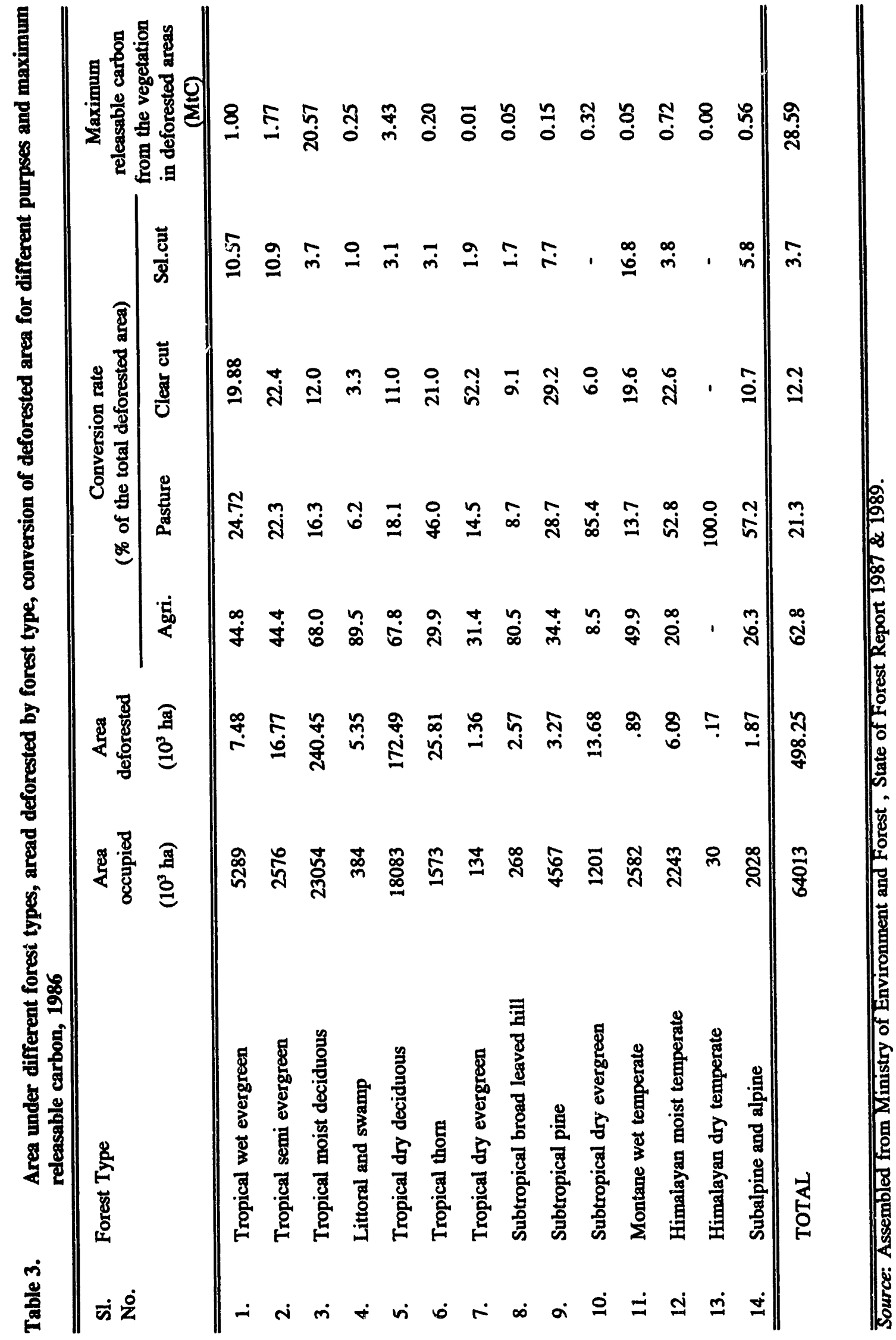


The net area deforested in each state and the total marginal deforestation is given in the last column of Table 2. Thus, the net area deforested in the reference year is estimated to be 498,250 ha. Because this area only covers the states where forest cover declined between the two assessments, this estimate may under-estimate deforestation of primary forests. However, the states where the forest area increased between 1982 and 1986 were included in the estimation of carbon uptake.

\subsection{Conversion of deforested area for different purposes}

Details on the conversiun of deforested areas for different uses disaggregated for individual states are available for the period 1951-75 (Central Forestry Commission 1981). Using this statelevel data, it is possible to obtain Jetails on the different purposes for which each forest type is being converted. The same proportions of total deforested area diverted for different purposes between 1951 and 1975 (Table 4) are used for the reference year of this study. In this study, forest conversions fall into four broad categories: agriculture, pasture, clear cutting and selective cutting. The transformation of forested areas to river valley projects and roads is considered clear cutting, conversion to crop lands is designated as agriculture, conversion for industrial lands is selective cutting and conversion to other purposes is considered as conversion to pasture.

By considering the rates of conversion of deforested area to different purposes at the state level and the area under different forest types in that state, the proportion of deforested area diverted to each of the four purposes is calculated for each forest type at the national level for application in the COPATH model. The proportions are given in Table 3. At the national level, ccsversion to agriculture dominated all other conversion purposes, accounting for 62.6 percent of the area deforested, followed by pasture and clear cutting.

\section{BIOMASS DEMANDS ON INDIAN FORESTS}

The biomass demands on forests are considered under three headings: combustion, long-term use and short-term use. It is very difficult to estimate the quantity of different types of biomass removed from different forest types as well as the contribution of the deforested area in meeting various biomass demands. Thus, the current consumption levels as given in Tables 5 and 6 are used to estimate and forecast the demand for woodfuel and biomass for short- and long-term.

\subsection{Combustion (firewood)}

Firewood is the dominant source of fuel for cooking in rural areas ( 95 percent of households depend on biomass in the form of firewood, crop residue and/or dung) and is a less important energy source in urban areas (used in about 16 percent of households in urban areas; Reddy and Reddy 1983). According to the (Ministry of Environment and Forests 1987), the total firewood consumption in 1987 was 157 million tonnes (mt), or 286 kilograms (kgs)/annum per capita. This figure does not include crop residues and dung. The different sources of firewood are forests, village trees, shrubs and weeds (e.g., Prosopis juliflora) and plantation tree crops (e.g., coconut, arecanut tea and rubber). The combustion of fuelwood leads to the release of $\mathrm{CO}_{2}$. Firewood in the form of twigs and branches, if harvested in a sustainable way, will not make any net $\mathrm{CO}_{2}$ contribution. However, if trees and branches are felled for fuel purposes in a nonsustainable way and burnt, there are net emissions of $\mathrm{CO}_{2}$. 
Table 4. Diversion of forest area for various purposes

\begin{tabular}{llcccc}
\hline Causes & $\begin{array}{l}\text { Conversion taken in } \\
\text { the present study }\end{array}$ & $\begin{array}{c}\text { Area lost } \\
\text { during } \\
1951-75 \\
\left(10^{3} \mathrm{ha}\right)\end{array}$ & $\begin{array}{c}\text { \% of area } \\
\text { lost to } \\
\text { total } \\
(\%)\end{array}$ & $\begin{array}{c}\text { Area lost/year } \\
\text { between 1981-83 } \\
\text { \& 1985-87 } \\
\left(10^{3} \mathrm{ha}\right)\end{array}$ & $\begin{array}{c}\text { \% lost to } \\
\text { the total } \\
\text { forest area }\end{array}$ \\
\hline Agriculture & Agriculture & 2520 & 0.625 & 313.02 & 0.4875 \\
$\begin{array}{l}\text { River valley projects } \\
\text { and roads }\end{array}$ & Clear Cutting & 479 & 0.119 & 60.61 & 0.0944 \\
Industries & 57 & 0.014 & & \\
$\begin{array}{l}\text { Miscellaneous } \\
\text { purposes }\end{array}$ & Selective cutting & 168 & 0.042 & 18.53 & 0.0289 \\
\hline \hline Total & Pasture & 803 & 0.199 & 106.08 & 0.1652 \\
\hline
\end{tabular}

Note: Since statewide details of deforestation for various purposes were available only for the years 1951-75 (Central Forestry Commission 1981) the same proportions have been used as the basis for allocating the area deforested for various purposes in different states during 1981-83 and 1985-87.

Table 5. Firewood, crop residues and dung as fuel ( $10^{\circ}$ tonnes)

\begin{tabular}{lccc}
\hline Year & Fuelwood & Crop residue & Dung \\
\hline \hline $1953-54^{\circ}$ & 86.3 & 26.4 & 46.4 \\
$1960-61^{\circ}$ & 99.6 & 30.6 & 64.5 \\
$1965-66^{\circ}$ & 109.3 & 33.6 & 59.9 \\
$1970-71^{\circ}$ & 117.9 & 36.3 & 64.6 \\
$1975-76^{\circ}$ & 133.1 & 41.0 & 73.0 \\
$1986^{\circ}$ & 157 & - & - \\
$2011^{\circ}$ & 190.8 & - & - \\
\hline \hline
\end{tabular}

Sources: a. Department of Environment, Forests and Wildlife 1986

b. Forest Survey of India 1988

c. Projected Figure

Note: Projected population for 2011 is 1287.18 million, calculated using a decimal growth rate of 23.50 between 198:-91 (74.3\% rural and 25.7\% urban). Entire rural and 16.1\% (Reddy and Reddy 1989) of urban people are dependent on fuelwood. Using a demand of $286 \mathrm{kgs}$. wood/capita/year (obtained by dividing $157 \mathrm{mt}$ by the size of the population using firewood) and a 33 percent savings due to improved efficiency, a value of zer capita wood requirement of $189 \mathrm{kgs} /$ year is considered.

$$
1-8
$$


Table 6. Long-term and short-term use category demand $\left(10^{6} \mathrm{~m}^{3}\right)$

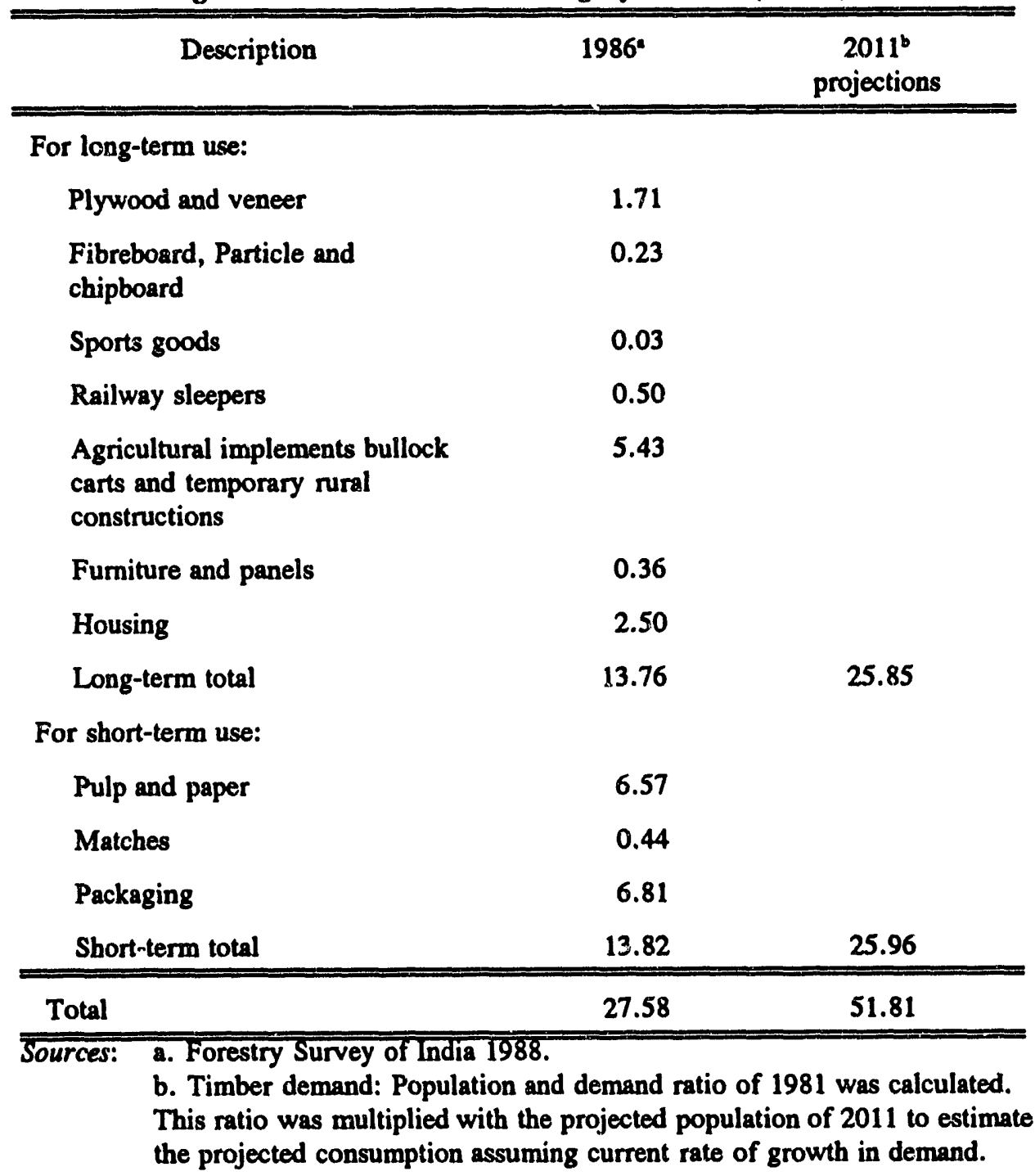

It is difficult to estimate what proportion of the $157 \mathrm{mt}$ of firewood comes from forests and, further, how much of the total is harvested in a non-sustainable manner. This study assumes that firewood comes from a number of sources including: clear felling for development projects, etc., the culling of wood resources from existing forests and shifting cultivation. For details on the calculations see Appendix I.

\subsection{Short-term use}

Wood used in pulp, paper, packaging, the match industry, etc. is considered as short-term use. The demand was officially estimated to be 13.82 million cubic meters $\left(\mathrm{m}^{3}\right)$ for the reference year (Ministry of Environment and Forests 1987). The sources for obtaining timber for short-term uses are forests and tree plantations. 


\subsection{Long-term use}

Long-term use consists of timber use for housing, agricultural implements, plywood, mining pit props, railway sleepers, etc. The total long-term use assumed for the reference year (based on Ministry of Environment and Forest 1987) was 13.76 million $\mathrm{m}^{3}$. The sources of timber for long-term use are forests (particularly as a source of timber for various structural materials, plywood and mining pit props), tree plantations and trees in village ecosystems (which are not considered forests).

\subsection{Standing biomass in forests}

Data on standing biomass for different forest types was obtained from the literature (references and values given in Appendix II). The maximum estimates of standing biomass recorded for each forest type is used in this study, undar the assumption that it has 100 percent crown cover.

the State of Forest Report 1989 gives the crown cover of forests in each state. Tiwwari and Singh (1987) have provided estimates of biomass under five different levels of crown cover for some forest types. This information was extrapolated to cover other forest types. Using the data on standing forest biomass under full crown cover and the estimated mean crown cover for each forest type, the total standing biomass was calculated for each forest type (Table 7). The total standing biomass in Indian forests is estimated to be $8357.9 \mathrm{mt}$ with a mean per ha standing biomass of $130.5 \mathrm{t}$.

\section{HISTORICAL AND CURRENT TRENDS IN CARBON FLUX}

\subsection{Carbon storage}

Carbon storage in the vegetation and soil is given in Table 8. The average carbon content of the biomass is estimated to be 50 percent. The estimates of carbon storage in forest soil are based on the soil organic carbon content in the soils of different forest types as stated in the literature (references and values are given in Appendix III).

The total carbon stored in Indian forests is estimated to be $9578 \mathrm{mt}$, of which vegetation and soil account for 43.6 and 56.4 percent respectively.

\subsection{Carbon uptake in forests}

In order to calculate the net carbon release, the carbon uptake and the carbon storage in forests, perennial plantation crops (like rubber, apple, tea, coffee, coconut) and tree plantations (like Eucalyptus, Casuarina equisetifolia) must be considered. 
Table 7. Production and Standing Biomass in Forests, 1986.

\begin{tabular}{lrcrr}
\hline \multicolumn{1}{c}{ Forest Type } & $\begin{array}{c}\text { Area } \\
\text { occupied }\end{array}$ & $\begin{array}{c}\text { Standing } \\
\text { Biomass }\end{array}$ & $\begin{array}{c}\text { Average } \\
\text { crown } \\
\text { cover }\end{array}$ & $\begin{array}{c}\text { Total standing } \\
\text { biomass }\end{array}$ \\
\hline 1. Tropical wet evergreen & 5289.3 & 607.7 & $(\%)$ & $\left(10^{6} \mathrm{t}\right)$ \\
2. Tropical semi evergreen & 2575.7 & 468.0 & 0.4782 & 1496.55 \\
3. Tropical moist deciduous & 23054.7 & 409.3 & 0.4259 & 576.46 \\
4. Littoral and swamp & 383.4 & 213.8 & 0.4426 & 4018.56 \\
5. Tropical dry deciduous & 18083.3 & 93.8 & 0.4313 & 36.30 \\
6. Tropical thom & 1573.0 & 40.0 & 0.3989 & 731.51 \\
7. Tropical dry evergreen & 134.2 & 40.0 & 0.4156 & 25.10 \\
8. Subtropical broad leaved hill & 267.8 & 108.7 & 0.3818 & 2.23 \\
9. Subtropical pine & 4567.5 & 210.8 & 0.4581 & 11.11 \\
10. Subtropical dry evergreen & 1201.0 & 159.7 & 0.2901 & 441.10 \\
11. Montane wet temperate & 2581.9 & 237.67 & 0.4875 & 55.63 \\
12. Himalayan moist temperate & 2242.8 & 562.2 & 0.4263 & 299.15 \\
13. Himalayan dry temperate & 30.5 & 169.1 & 0.4079 & 537.50 \\
14. Subalpine and alpine & 2027.7 & 127.4 & 0.4822 & 2.10 \\
\hline \hline TOTAL & 64013.0 & -- & -- & 124.56 \\
\hline \hline
\end{tabular}

Notes: a. Average crown cover and standing biomass was calculated using data on standing biomass under lower canopy from Tiwari and Singh (1987).

b. See Appendix II for references on standing biomass. 
Table 8. Carbon flows: curreat and future scemarios (million tons)

\begin{tabular}{|c|c|c|c|}
\hline Carton Flux & 1986 & $\begin{array}{l}2011 \\
\text { (at current mates) }\end{array}$ & $\begin{array}{c}2011 \\
\text { (at favorable rates) }\end{array}$ \\
\hline \multicolumn{4}{|l|}{ CARBON STORAGE: } \\
\hline \multicolumn{4}{|l|}{ Fored } \\
\hline - vegetation & 4178.95 & 4178.95 & 4178.95 \\
\hline - soil & 5399.33 & 5399.33 & 5399.33 \\
\hline Plantation & - & 850.50 & 1181.25 \\
\hline Penennial: & - & 75.00 & 3000.00 \\
\hline Natural regeneration & - & - & 1096.87 \\
\hline Total & 9578.28 & 10503.78 & 14856.40 \\
\hline \multicolumn{4}{|l|}{ CARBON RELEASE } \\
\hline Shifting cultivation & 1.56 & 1.560 & 1.560 \\
\hline Combustion & 31.97 & 61.660 & 31.850 \\
\hline Past long-term use & 1.38 & 4.610 & 4.610 \\
\hline Past shon-lerm use & 3.10 & 5.908 & 5.908 \\
\hline Current short-term use & 2.84 & 2.954 & 2.954 \\
\hline Release from soil & 3.91 & 3.910 & 3.990 \\
\hline $\begin{array}{l}\text { Biomass decomposition } \\
\text { (surface and underground) }\end{array}$ & 18.82 & 18.820 & 18.820 \\
\hline Total & 63.58 & 99.422 & 69.692 \\
\hline \multicolumn{4}{|l|}{ CARBON UPTAKE } \\
\hline Forest & 68.87 & 68.870 & 68.870 \\
\hline Natural regeneration & - & 0.225 & 9.375 \\
\hline Afforestation (short rotation forestry) & - & 27.000 & 37.500 \\
\hline Reforestation & - & - & 75.000 \\
\hline Total & 68.87 & 96.095 & 190.745 \\
\hline
\end{tabular}


Only in mature or climax forests is all the gross primary productivity of biomass and living tissue either used up in respiration or returned to the soil as litter. Therefore, there is no net addition to the standing biomass in these forests. At all other stages of succession, there is a net addition to the standing biomass (carbon accumulation). Large tracts of forests in India have been subjected to anthropogenic factors over the centuries; thus, the nation's forests are at various stages of succession. For example, the 64.01 million ha of forest considered in the study include a cumulative area of 11.4 million ha afforested between 1952 to 1986 (Ministry of Environment and Forests 1989) and several plantation crops like rubber coffe and tea.

The net annual accumulation for the reference year is calculated using data on the net primary productivity (NPP), or mean annual increment (MAI), and standing biomass from various studies (See Appendix IV for References). Only the accumulation of biomass in the main trunk and large branches is considered for calculating carbon uptake. Productivity in the form of leaf litter and micro-wood litter is not considered, as it is likely to end up decomposing. The net accumulation of woody biomass considered in the study lies in the range of 3.28 to 8.84 $\mathrm{t} / \mathrm{ha} /$ year. Based on the above figures, the net accumulation of carbon in Indian forests is estimated to be $68.87 \mathrm{mt}$ for the year 1986 (Table 8).

\subsection{Carbon emissions}

Carbon emissions from forests stem from deforested areas as well as from unrecorded depletion plus degradation in existing forest areas. The carbon emission values are given in Table 9. The total carbon emissions from all the natural and anthropogenic factors affecting the forest are estimated to be $63.58 \mathrm{mt}$. The following section disaggregates this total according to four major sources.

\subsubsection{Carbon emissions from clear-felled forests}

This study assumes that the firewood component of annual removal from forests comes from deforested areas (Ministry of Environment and Forests 1987). Thus, $13.5 \mathrm{mt}$ of carbon is estimated to be released from combustion in clear felled areas. In the case of carbon release from long-term use, this work assumes that timber dedicated to long-term purposes has a life span of 30 years. Based on this assessment, the carbon estimate for the reference year includes releases from the timber used for long-term products 30 years prior to the reference year. Due to this inclusion, the emissions in the reference year will not equal the stored carbon in the deforested vegetation For this reason, there is no balance between the total biomass from felled areas $(28.59 \mathrm{mt}$, see Table 3$)$ and the total carbon released from deforested areas $(27.65 \mathrm{mt}$, see Table 9). Regarding short-term use, the quantity of wood or timber used is expected to last for only three years. Accordingly, the biomass used for short-term purposes three years prior to the base year is assumed to release carbon in the base year; in addition, one-third of the carbon devoted to short-term products in the reference year is assumed to be released during that same year. Releases of carbon from soil was calculated based on Ayanaba et al. (1976), while biomass decomposition was calculated based on values by FRI (1970). 


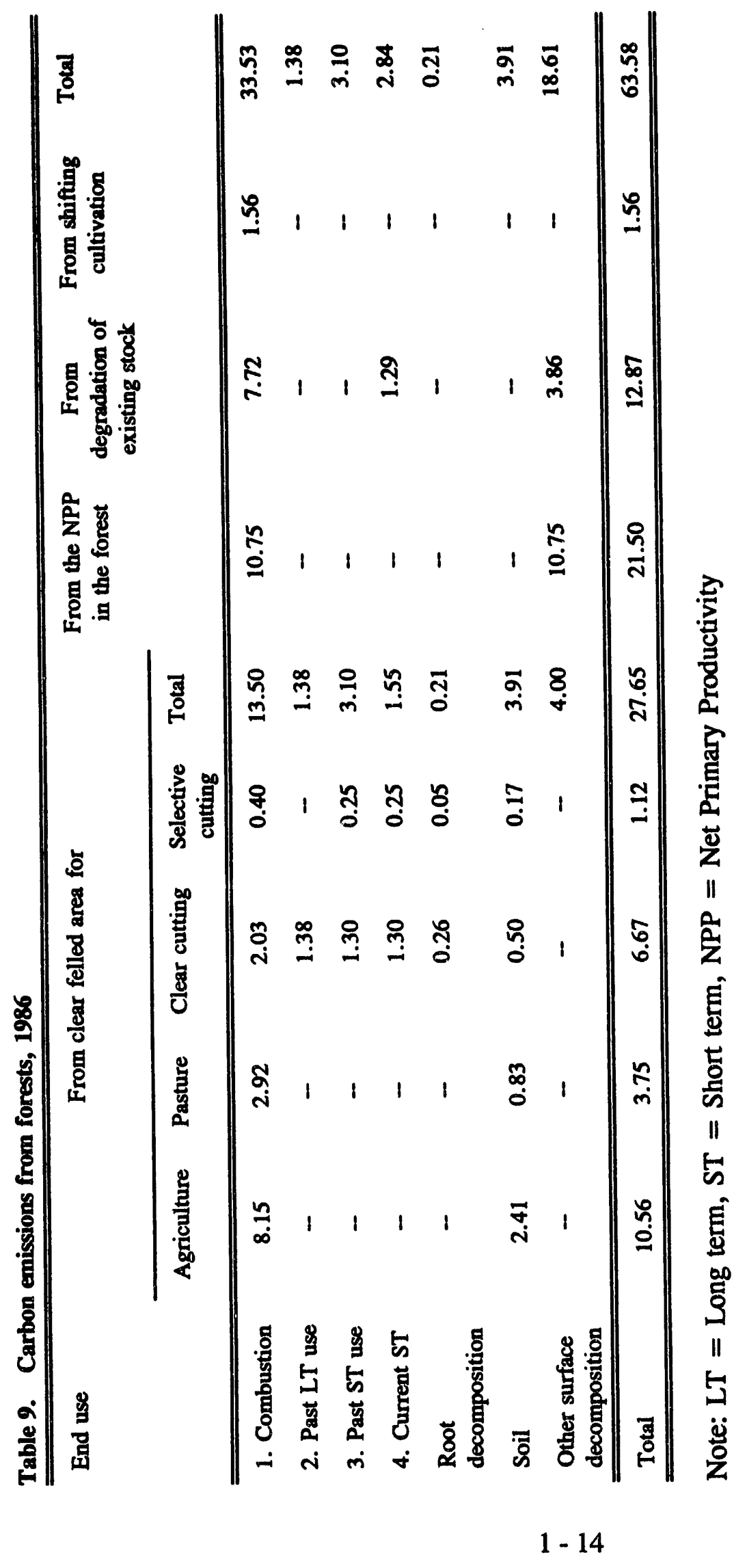


The total carbon released from various conversions (like combustion, short- and long-term use and decomposition) is estimated to be $27.65 \mathrm{mt}$. (Table 9).

\subsubsection{Carbon emissions from current year's production}

Total NPP was obtained from biomass studies for different forest types (Appendix IV). Out of the total net primary productivity of $137.7 \mathrm{mt}$ of carbon, 69 percent assumably accumulates in bole and big branches for long-term storage. Of the remaining current year's production, 50 percent is considered to be used as fuelwood and the remaining 50 percent is assumed to be left for decomposition.

The total carbon released from the reference year's production in forests for combustion and decomposition is estimated to be $21.5 \mathrm{mt}$. (Tabble 9).

\subsubsection{Carbon emissions from forest degradation and illegal removal}

In addition to the carbon released from deforestation or clear felling, the degradation of existing forests also contributes to the release of carbon. Degradation can result from grazing, fires, diseases and pest attacks, illegal removal of timber and over-harvesting for fuelwood. Several studies site evidence of these activities (Brown et al. 1991; Flint and Richards 1991). The analysis carried out by Flint and Richards (1991) for southern Asia (including northern parts of India) indicates a degradation ratio (the ratio of biomass lost to area lost relative to the initial biomass) of 1.54 for the period 1950-80. One interpretation according to Houghton (1991) is that for every tonne of carbon released into the atmosphere through deforestation, an additional $0.54 \mathrm{t}$ of carbon is released from degradation of the standing forests. Thus, out of the total carbon emission of $27.65 \mathrm{mt}$ from deforestation, the amount emitted due to degradation factors is $15.0 \mathrm{mt}$. Out of this total, about half is assumed to be used as fuelwood $(7.72 \mathrm{mt})$, and the balance is equally divided between decomposition (3.86 $\mathrm{mt})$ and short term use (3.86 $\mathrm{mt})$.

The carbon released due to degradation and unaccounted for removal is estimated to be 12.87 $\mathrm{mt}$ for the reference year.

\subsubsection{Carbon emissions from shifting cultivation}

About 0.99 million ha are annually subjected to shifting cultivation (Ministry of Environment and Forests 1987). The fallow period is continually shortened. Considering the shortened fallow periods, net carbon emissions are estimated at $1.56 \mathrm{mt}$ (Table 9). This total accounts for new accumulation in areas left fallow and degradation or burning of new areas.

\subsection{Net carbon releases}

At the global level, deforestation is estimated to contribute 1.5-3.6 Gt of carbon annually (Houghton 1990). It is not clear whether the carbon sequestered in the existing forests and in the new forest plantations each year is considered in the various global estimates. For example, 
Myers (1989) considers a deforestation rate of 0.4 million ha annually for India and, correspondingly, $41 \mathrm{mt}$ of carbon is estimated to be released to the atmosphere; Myers' estimate does not account for sequestered carbon. Ahuja (1990) has made an estimate of the net carbon emissions, based on values of global flux of 0.7 pentagrams (pg) of carbon (Lashof and Tirpak 1989 ) and the assumption that India's share in global deforestation is 20.2 tetragrams ( $\mathrm{tg}$ )/year. Because Indian forestry is considered as an ecosystem, what is of consequence to climate change is the net carbon release after accounting for both annual emissions from deforestation and forest degradation and total long-term sequestration (or the annual accumulation resulting from net primary productivity in bole and large branches) in forests and tree plantations.

When the net carbon flow in the Indian forest ecosystem is considered (carbon uptake - carbon release), a marginal net carbon sequestration of $5.29 \mathrm{mt}$ results for the reference year (Table 8). This figure, however, does not include carbon emitted in the base year due to deforestationrelated activities in previous years.

\subsection{Explanation for no net carbon releases}

India has witnessed a surge in efforts aimed at protecting forest resources and afforesting exploited forest regions over the past two decades. As a result, carbon uptake from India's forestry sector has increased. Based on an analysis of these trends, this study estimates that the contribution of Indian forests to the atmospheric build up of $\mathrm{CO}_{2}$ is far less than previously estimated; in fact, Indian forests may sequester more carbon than they emit. The following factors have all served to reduce net emissions by the forestry sector:

(i) The Forest Conservation Act of 1980 prescribes that no land should be alienated from the control of state forest departments without the consent of the central government. In the Indian context, obtaining permission from the central government is a very difficult task, as is reflected in the official statistics which indicate an essential halt to the process of deforestation.

(ii) Beginning with the Fifth Five-Year Plan of 1975-80, it became compulsory for all major development projects to carefully prepare an environmental impact statement and to provide for compensatory afforestation in the event of the loss of any forest cover.

(iii) Beginning in the late 1970s, the high levels of subsidies enjoyed by the forest-based industries have been gradually reduced, thereby helping to motivate the industries to use forest resources more carefully.

(iv) Since the 1970s, Indian farmers have been encouraged to produce tree crops. In addition, many industries and farmers have developed healthy links with one another in order to fulfill the needs of forest-based industries.

(v) Local tribes and villages increasingly have been given an economic stake in the wellbeing of local forest resources. The first example of this trend were the Village Forest 
Protection Committees of West Bengal. The response has been most encouraging. Other states like Haryana and Gujarat have initiated measures to create community-based management systems at the village level for involving the local people in sustainable use and restoration of the local forest resources.

(vi) Over the past two decades, many state governments have decentralized their political decision-making (e.g., West Bengal in the late 1970s and Karnataka in the mid-1980s). As a result, village and district level political authorities have been established that are far more motivated to ensure the prudent use of local resources -- including forest resources. Other states are expected to follow suit in decentralizing power, thus creating more favorable conditions for better management of forest resources. Further, the National Wastelands Development Board, created in 1985, has taken novel initiatives in decentralizing integrated planning in the use of natural resources and is spearheading efforts to restore the vegetation cover on vast stretches of degraded lands by meaningfully involving the local people.

(vii) India has launched a very large afforestation program. The area afforested in recent years is given below (Ministry of Environment and Forests 1989a).

Year

1985-86

1986-87

$1987-88$

$1988-89$
Area Afforested

1.51 million ha

1.76 million ha

1.77 million ha

2.12 million ha

The above data indicates that large areas have been brought under tree vegetation. These new forest areas were priorly deforested or degraded community lands, or degraded private lands. Studies of plantations raised by the forest department as well as farmers have shown a productivity in the range of 1.3 to $8.3 \mathrm{t} / \mathrm{ha} / \mathrm{yr}$ (Ravindranath et al., 1992). This substantial biomass productivity has contributed significantly to the increased uptake by growing forests in India.

(viii) Above all, the strong environmental movements in different parts of the country, with the very active support of the mass media, have contributed significantly to reducing large-scale legal and illegal conversions of forest land.

(ix) Biomass fuel conservation programs like biogas utilization and the use of efficient stoves are being implemented in all the states. Such programs lead to diminished levels of biomass-related deforestation.

(x) A large section of the forest with less than 40 percent crown cover is under successional and is therefore actively sequestering carbon, albeit at a reduced rate than plantations. 


\section{FUTURE SCENARIOS OF CARBON FLOW}

To provide an estimate of the possible ievels of carbon emissions in the future, this section presents two medium-term scenarios for the year 2011. The carbon flux values for the scenarios are given in Table 8.

\subsection{Assumptions}

Scenario I: In this scevario, current rates of deforestation, afforestation, firewood consumption, productivity, long-term and short-term timber uses, etc. are maintained from 1986-2011. The area under plantations and perennials (coffee, tea, rubber, etc.) continues to increase at current rates.

Scenario II: This more favourable scenario assumes the following changes:

- Short-term forestry (firewood and soft wood) increases by 2.5 million ha/year.

- $\quad$ Long-term forestry rises by 2 million ha/year.

- Area to be brought under natural regeneration expands by 1 million ha/year.

- Produciivity of plantations rises by $3 \mathrm{t}$ of carbon/ha/year.

- Productivity of land under natural regeneration grows by $0.75 \mathrm{t}$ of carbon/ha/year.

- Number of biogas plants for cooking increases by 0.5 million/year.

- All houses gain access to efficient cook stoves (at a savings of 33 percent in fuel use).

- The area under forests remains unchanged, but the area under perennials (like rubber, coconut, tea, coffee) and forest plantations increases at current rates.

\subsection{Results}

Scenario I: The business-as-usual scenario for the year 2011 shows that with an increase in population there would be a relative increase in demand for biomass from forests and plantations. If the current proportion of demand for firewood and timber being met from the forests is assumed for 2011, Indian forests would produce $99.42 \mathrm{mt}$ of carbon that year. Thus, the business-as-usual scenario is not environmentally sound given a large increase in the population.

Such a scenario is not likely to be realized as a result of several factors:

(i) Biomass fuel conservation programs are being implemented rigorously.

(ii) The area afforested annually is likely to go up from the assumed rate of 1.8 million ha. Even farmers are likely to shift from marginal cropping to tree cropping.

(iii) There is likely to be a shift from wood to other materials, like steel, plastics and reinforced cement concrete, for structural purposes and packaging. 
(iv) The increased participation of communities in the management of forests and community plantations should lead to sustainable harvests.

Scenario II: The favorable assumptions made for this scenario do not appear unrealistic. All the assumptions are plausible. Under this scenario, Indian forests sequester $121.05 \mathrm{mt}$ of carbon. This scenario highlights the great contribution the forestry sector can potentially make at both the local and global level.

\section{CONCLUSION: FORESTRY FOR GLOBAL AND LOCAL BENEFITS}

This study estimates that forest land conversions in India generated 63.58 million tonnes of carbon emissions in 1986. Agriculture accounted for the largest share of all emissions from clear-felled areas, foilowed by clear cutting. According to the estimate, carbon uptakes for forest lands reached 68.87 million tonnes of carbon that year

One long-term scenarios indicates that if carbon releases were to continue to grow at current rates for the 25 years following the base year, carbon releases would rise by 56 percent of the 1986 value. In contrast, a more optimistic scenario for the same time span suggests that India would witness a far smaller increase in emissions by 2011 , equalling only 10 percent of the base year value. The most striking difference between the two long-term scenarios is the variation in carbon uptake for 2011. In the favorable scenario, carbon uptake is almost three times higher in 2011 than in 1986 and just under twice as high as in the business-as-ussal scenario for 2011.

This study seeks to illustrate the extent of the activities underway that have served to increase carbon uptake and stem previously high rates of deforestation. As a result of these efforts, carbon uptake appears to have risen to levels high enough to offset emissions resulting from current deforestation. If this finding is accurate, India may not be adding to the build up of $\mathrm{CO}_{2}$ in the global atmosphere.

The favorable scenario (II) shows the large potential for increasing carbon sequestration. The primary goals of pursuing these options in India would be to promote biological diversity, watershed development and sustainable biomass use. Carbon sequestration with its global benefits would be a very important outcome of any good forest strategy. It is possible to promote a forestry strategy which provides local as well as global benefits. Such a strategy would involve the following important factors:

1. All the wood required for commercial purposes (mainly for short-term use) should be met from privately owned degraded crop lands. Appropriate incentives have to be provided to farmers to encourage them to shift from marginal-cropping to tree-farming on such degraded crop lands.

2. The subsistence biomass needs of tribal and rural populations could be met from a network of community lands near their habitats in a sustainable way. 
3. The reserve forest lands (including the degraded forest areas) should be brought under a regime of production restricted to non-wood forest products for employment and income generation to tribal and rural communities.

4. The local communities must be empowered with the ability to sustainably manage the common lands as well as the reserved forests.

5. Biomass fuel conservation programs must be implemented more vigorously. Biomass fuel conservation could lead to a significant net reduction in the release of greenhouse gases.

6. The potential for developing bio-energy technologies and options for power generation at the decentralized level to meet village energy needs in a sustainable way should be explored. The substitution of fossil-fuel based energy with bio-energy systems would lead to a net reduction in greenhouse gases (Hall et al. 1991).

All of these strategies have a strong bias towards assuring local benefits and would lead to increased storage of carbon in the existing forests and to new sequestration of carbon in currently degraded areas. As a result, a significant amount of carbon would be sequestered for global benefits. The economic, social and political implications of such a strategy have to be analyzed carefully.

\section{ACKNOWLEDGEMENT:}

This study was done as a part of the F-7 Network organized and coordinated by Jayant Sathaye and Willy Makundi of the Lawrence Berkeley Laboratory, University of California, Berkeley, USA. Part of the project was carried out using the funds provided by the Ministry of Environment and Forests, Government of India, New Delhi to the Centre for Ecological Sciences, Indian Institute of Science, Bangalore. This report benefited from comments by Professor David Hall of Kings College U.K., and Dr. Dilip Ahuja of The Bruce Company, Washington D.C. 


\section{APPENDIX I: SOURCES OF FIREWOOD}

\section{From deforestation}

This study assumes that all the recorded production of firewood $(27 \mathrm{mt})$ came from the official estimates of deforested area (Ministry of Environment and Forests, 1988); the remaining 130 $\mathrm{mt}$ of firewood came from other sources. Of the total recorded fuelwood produced, $17.7 \mathrm{mt}$ came from the area deforested for agriculture, while $5.3 \mathrm{mt}, 3.4 \mathrm{mt}$ and $0.6 \mathrm{mt}$ came from the areas deforested for pasture, clear cutting and selective cutting respectively.

2. From the net primary productivity (NPP) of woody biomass in the forest

Biomass accumulated annually in the forest through NPP is $137.7 \mathrm{mt}$. Studies (Rai, 1981; Rana 1985; Sharma et al. 1990) have shown that about $48-74$ percent of the NPP accumulates in the bole. Thus, about $94.7 \mathrm{mt}$ remain in the bole fraction and about $43 \mathrm{mt}$ are available in the form of small twigs and branches. Out of the latter share, only 50 percent $(21.5 \mathrm{mt})$ is considered extractable firewood; the remaining micro-litter is likely to end up decomposing (Table 9).

\section{From the degradation of existing stock}

At a degradation ratio of 1.54 , the biomass that would come from degraded sources is estimated to be $30.88 \mathrm{mt}$ out of which $15.44 \mathrm{mt}(50 \%)$ is available as firewood and the remaining part may end up partly for short-term or long-term use and partly for decomposition (Table 9).

\section{From shifting cultivation}

From an annual area of 0.99 million ha under shifting cultivation, an amount of wood equivalent to $3.12 \mathrm{mt}$ is assumed to be burnt (Table 9).

Altogether firewood from forests totals $67.6 \mathrm{mt}$. The rest of the firewood $(89.94 \mathrm{m.t.})$ may come from (i) trees in the village ecosystems, (ii) shrubs like Prosopis juliflora, Lantana camera and Cassia auriculata, and (iii) plantation crops like tea, coffee, rubber and coconut. 
APPENDIX II: MAXIMUM STANDING BIOMASS OF DIFFERENT FOREST TYPES

\begin{tabular}{|c|c|c|c|}
\hline & Forest type & Standing biomass (t/ha) & Reference \\
\hline 1. & Trop. wet evergreen & 607.7 & Rai 1981 \\
\hline 2. & Trop. semi evergreen & 468.0 & Swamy 1989 \\
\hline 3. & Trop. moist deciduous & 409.3 & Swamy 1989 \\
\hline 4. & Littoral \& swamp & 213.8 & Singh 1989 \\
\hline 5. & Trop. dry deciduous & 93.8 & Singh 1990 \\
\hline 6. & Trop. thom' & 40.0 & - \\
\hline 7. & Trop. dry evergreen ${ }^{2}$ & 40.0 & - \\
\hline 8. & Sub trop. broad-leaved hill & 108.7 & Toky \& Ramakrishnan 1982 \\
\hline 9. & Sub trop. pine & 210.8 & Chaturvedi \& Singh 1984 \\
\hline 10. & Sub trop dry evergreen ${ }^{3}$ & 159.7 & $\cdots$ \\
\hline 11. & Montane wet temp. & 237.67 & Yadava 1986 \\
\hline 12. & Himalayan moist temp. & 562.2 & Rana 1985 \\
\hline 13. & Himalayan dry temp & 169.1 & -- \\
\hline 14-16. & Subalpine \& alpine & 127.4 & Yoda 1968 \\
\hline
\end{tabular}

Notes: 1. Tropical thom forests were assumed to have $\mathbf{4 0}$ percent crown cover of tropical dry deciduous forests as they appear along side the tropical dry deciduous forests; $\mathbf{4 0}$ percent of the standing biomass of deciduous forests vere assumed to be the standing biomass of tropical thorn forests, which is $37.52 \mathrm{t} / \mathrm{ha}$ further rounded off to $40 \mathrm{t} / \mathrm{ha}$.

2. Same as tropical thom forests.

3. Since it occurs between subtropical pine and tropical dry deciduous forests a mid value between the standing biomass values of these two forests types is taken.

4. Since it occurs between subtropical pine and sub alpine forests, a mid value between the standing biomass values of these two forest types is taken. 


\section{APPENDIX III: SOIL CARBON IN DIFFERENT FOREST TYPES}

\begin{tabular}{|c|c|c|}
\hline Forest Type & Soil carbon (t/ha) & Reference \\
\hline \multirow[t]{2}{*}{ 1. Tropical wet evergreen } & 125.19 & \multirow{3}{*}{$\begin{array}{l}\text { Singh } 1968 \\
\text { Rajamannar \& Krishna moorthy } 1978\end{array}$} \\
\hline & 140.4 & \\
\hline Mean & 132.79 & \\
\hline \multirow[t]{3}{*}{ 2. Tropical semievergreen } & 152.9 & \multirow{3}{*}{$\begin{array}{l}\text { Singh } 1968 \\
\text { Swamy } 1989\end{array}$} \\
\hline & 190.6 & \\
\hline & 171.75 & \\
\hline \multirow[t]{5}{*}{ 3. Tropical moist deciduous } & 40.17 & \multirow{5}{*}{$\begin{array}{l}\text { Das } 1975 \\
\text { Rajamannar \& Krishna moorthy } 1978 \\
\text { Banerjee et al. } 1986 \\
\text { Jha et al. } 1979\end{array}$} \\
\hline & 42.12 & \\
\hline & 67.08 & \\
\hline & 79.17 & \\
\hline & 57.135 & \\
\hline \multirow[t]{4}{*}{ 4. Littoral \& swamp } & 26.52 & \multirow{4}{*}{ I Sahoo et al. 1989} \\
\hline & 29.25 & \\
\hline & 34.90 & \\
\hline & 30.22 & \\
\hline \multirow[t]{4}{*}{ 5. Tropical dry deciduous } & 51.87 & \multirow{5}{*}{$\begin{array}{l}\text { Kumar et al. } 1987 \\
\text { Sachan et al. } 1980 \\
\text { Singh et al. } 1990 \\
\text { Singhal \& Sharma } 1983\end{array}$} \\
\hline & 54.21 & \\
\hline & 61.16 & \\
\hline & 64.74 & \\
\hline Mean & 57.99 & \\
\hline 6. Tropical thom & 44.0 & (1) \\
\hline 7. Tropical dry evergreen & 33.0 & $(2)$ \\
\hline
\end{tabular}

Notes: 1. Since no studies were available it was assumed that soil carbon in this forest type would be equivalent to $75 \%$ of soil carbon of tropical dry deciduous forests.

2. Since no studies were available, it was assumed that soil in this forest would contain carbon equivalent to $75 \%$ of soil carbon of tropical thorn forest.

(CONTINUED ON FOLLOWING PAGE) 
APPENDIX III: SOIL CARBON IN DIFFERENT FOREST TYPES (continued)

\begin{tabular}{|c|c|c|}
\hline Forest Type & Soil carbon (t/ha) & Reference \\
\hline \multirow[t]{3}{*}{ 8. Subtropical broad-leaved hill } & 94.37 & \multirow{4}{*}{$\begin{array}{l}\text { Mandal et al. } 1990 \\
\text { Banerjee et al. } 1986 \\
\text { Mandal et al. } 1990\end{array}$} \\
\hline & 111.93 & \\
\hline & 119.70 & \\
\hline Mean & 108.66 & \\
\hline \multirow[t]{5}{*}{ 9. Subtropical pine } & 73.9 & \multirow{5}{*}{$\begin{array}{l}\text { Singh et al. } 1990 \\
\text { Sachan et al. } 1981 \\
\text {-.- } \\
\text { Nair \& Chamuah } 1988\end{array}$} \\
\hline & 85.0 & \\
\hline & 88.14 & \\
\hline & 114.66 & \\
\hline & 90.425 & \\
\hline 10. Subtropical dry evergreen & 33.0 & $(1)$ \\
\hline \multirow[t]{2}{*}{ 11. Montane wet temperate } & 170.0 & \multirow{3}{*}{$\begin{array}{l}\text { Singh } 1990 \\
\text { Banerjee } 1986\end{array}$} \\
\hline & 206.7 & \\
\hline Mean & 188.35 & \\
\hline \multirow[t]{4}{*}{ 12. Himalayan moist } & 132.6 & \multirow{5}{*}{$\begin{array}{l}\text { Banerjee \& Badola } 1980 \\
\text { Sachan et al. } 1981 \\
\text { Rawat \& Kumar } 1989 \\
\text { Dhar \& Jha } 1983\end{array}$} \\
\hline & 132.6 & \\
\hline & 144.3 & \\
\hline & 152.1 & \\
\hline Mean & 140.4 & \\
\hline \multirow[t]{3}{*}{ 13. Himalayan dry temperate } & 71.4 & \multirow{3}{*}{$\begin{array}{l}\text { Singh \& Gupta } 1990 \\
\text { Negi \& Ghosh } 1980\end{array}$} \\
\hline & 78.0 & \\
\hline & 74.7 & \\
\hline \multirow[t]{4}{*}{ 14-16. Sub alpine and alpine } & 255.0 & \multirow{4}{*}{$\begin{array}{l}\text { Das et al. } 1988 \\
\text { Datta et al. } 1989 \\
\text { Gangopadhyaya } 1990\end{array}$} \\
\hline & 259.7 & \\
\hline & 259.7 & \\
\hline & 258.13 & \\
\hline
\end{tabular}

Notes: 1. Since no studies were available, it was assumed that soil carbon content would be similar to a value equivalent to 75 percent of that of tropical dry evergreen forests. 
APPENDIX IV: NET PRIMARY PRODUCTIVITY (NPP) in t/ha/yr.

\begin{tabular}{|c|c|c|c|c|c|c|}
\hline $\begin{array}{l}\text { Forest } \\
\text { Type }\end{array}$ & $\begin{array}{l}\text { Description } \\
\text { of } \\
\text { Forest type }\end{array}$ & $\begin{array}{l}\text { Standing } \\
\text { Biomass }\end{array}$ & $\begin{array}{l}\text { NPP of } \\
\text { Stem, } \\
\text { branch } \\
\text { \& twiggs }\end{array}$ & $\begin{array}{l}\text { NPP as } \\
\% \text { of St. } \\
\text { Biomass }\end{array}$ & Reference & $\begin{array}{l}\text { \% of } \\
\text { Forest } \\
\text { Cover }\end{array}$ \\
\hline 1. & $\begin{array}{l}\text { Tropical wet } \\
\text { Evergreen }\end{array}$ & 607.7 & 7.806 & 1.28 & Rai, 1981 & 8 \\
\hline 3. & $\begin{array}{l}\text { Tropical moist } \\
\text { deciduous }\end{array}$ & 588.9 & 8.59 & 1.46 & Rana, 1985 & 36 \\
\hline 5 & $\begin{array}{l}\text { Tropical dry } \\
\text { deciduous }\end{array}$ & 115.5 & 3.28 & 2.84 & $\begin{array}{l}\text { Sharma et al., } \\
1990\end{array}$ & 28 \\
\hline 9 & Sub tropical pine & 198.96 & 4.12 & 2.07 & Rana, 1985 & 7 \\
\hline 12 & $\begin{array}{l}\text { Himalayan moist } \\
\text { temperate }\end{array}$ & 432.8 & 8.98 & 2.07 & Rana, 1985 & 3 \\
\hline
\end{tabular}




\section{APPENDIX V: REFERENCES TO APPENDICES I-IV}

Banerjee, S.K., S. Nath and S.P. Banerjee. 1986. Phytosociology and Soil Characteristics of forests in the eastern Himalayas. Int. J. Trop. Ag. 4:116-12.5.

Banerjee, S.P. and K.C. Badola, K.C. 1980. Nature and Properties of Some Deodar (Cedrus deodara) Forest Soils of Chakrata Forest Division, U.P. Indian For. 558-560.

Chaturvedi, O.P. and J.S. Singh. 1984. Potential Biomass Energy from All Aged Chirpine Forest of Kumaun Himalaya. Biomass 5:161-165.

Das, D.K. 1975. Clay Minerals in Some Forest Soils. Indian Agric. 19:373-381.

Das, P.K., S. Nath and S.K. Banerjee. 1988. Characteristics of the Soils of Sub-alpine Region in the Eastern Himalayas. J. Indian Soc. Soil Sci. 36:576-580.

Datta, D.K., S.K. Gupta, S. Nath and S.K. Banerjee. 1989. Variations in the Characteristics and Nutrient Status of Soils of the Eastern Himalayas as Influenced by elevation. Int. J. Trop. Ag. 7:208-215.

Dhar, B.L. and M.N. Jha. 1983. Physical and Chemical Properties of Forest Soils of the Lesser Himalaya (H.P.). J. Tree Sci. 2:42-48.

Gangopadhyaya, S.K., P.K. Das, N. Mukhopadhyaya, S. Nath and S.K. Banerjee. 1990. Altitudinal Pattern of Soil Characteristics under Forest Vegetation in Eastern Himalayan Region. J. Indian Soc. Soil Sci. 38:93-99.

Jha, M.N., P. Pande and T.C. Pathak. 1979. Studies on the Changes in the Physico Chemical Properties of Tripura Soils as a Result of Jhuming. Indian For. 105:436-443.

Kumar, O., I.P. Saxena and H.N. Mathur. 1987. Study of the Soils of Eastern Doon Valley Forests. Indian J. For. 10:142-147.

Mandal, A.K., S. Nath, S.K. Gupta and S.K. Banerjee. 1990. Characteristics and Nutritional Status of Soils of Middle Hill and Upper Hill Forests of the Eastern Himalayas.

J. Indian Soc. Soil Sci. 38:100-106.

Nair, K.M. and G.S. Chamuah. 1988. Characteristics and Classification of Some Pine Forest Soils of Meghalaya. J. Indian Soc. Soil Sci. 36:142-145. 
Negi, A.A. and A.B. Ghosh. 1980. Profile Distribution and Physico Chemical Properties of the Soils from the Cold and Arid Regions of Himachal Pradesh. J. Indian Soc. Soil Sci. 28:396-398.

Rai, S.N. 1981. Productivity of Tropical Rain Forests of Karnataka. Ph.D. thesis, University of Bombay, Bombay.

Rajamannar, A. and K.K. Krishnamoorthy. 1978. A Note on the Influence of Altitude on the Physico Chemical Characters of Forest Soils. J. Indian Soc. Soil Sci. 26:399-400.

Rana, B.S. 1985. Biomass and Net Primary Productivity in Different Forest Ecosystems along an Altitudinal Gradient in Kumaun Himalaya. Ph.D. thesis, Kumaun University, Nainital.

Rawat, V.R.S. and P. Kumar. 1989. Ecological Studies of Some Cedrus Deodara (Deodar) Forests in Western Himalayas, India. Indian J. For. 3:315-319.

Sachan, R.S., R.B. Sharma and R.K. Chibber. 1980. Nature and Status of Organic Matter of Some Forest Soils of India as Influenced by the Heterogeneity of Plant Cover and Climatic Conditions. Indian J. For. 3:315-319.

Sachan, R.S., R.B. Sharma and R.K. Chibber. 1981. Nature and Status of Organic Matter of Some Hill and Forest Soils of Himachal Pradesh. Indian J.For. 4:249-252.

Sahoo, A.K., K.D. Sah and S.K. Gupta. 1989. Available Micro Nutrient Status of Some Mangrove Soils of the Sunderbans. Indian Agric. 33:141-146.

Sharma, R.B., M. Chandra and K.P. Singh. 1990. Variations in Forest Biomass and Productivity. In: Singh, J.S., K.P. Singh and M. Agrawal (eds.). Environmental Degradation of Obra-Renukoot-Singrauli Area and Its Impact on Natural and Derived Ecosystems. Final technical report, MAB Project, Banaras Hindu University, Varanasi.

Singh, J. 1990. Nature and Distribution of Soil Humic Substances of Some Plant Communities at Ooty, Nilgiri. Myforest. 26:143-147.

Singh, K.P. 1968. Nutrient Status of Forest Soils in Humid Tropical Regions of Western Ghats. Trop Ecol. 9: 119-130.

Singh, L. 1990. Biomass Production and Nutrient Dynamics in a Dry Tropical Forest. Ph.D. thesis, Banaras, Hindu University, Varanasi.

Singh, R., R.K. Singh and K. Singh. 1990. Effect of Different Plant Covers on Soil Characteristics. Indian For. 116: 795-802. 
Singh, R.P. and M.K. Gupta. 1990. Soil and Vegetation Study of Lahaul and Spiti Cold Desert of West Himalayas. Indian For. 116:785-790.

Singh, V.P. 1989. Mangarove Forests of Andaman Islands -- Their Structure, Status and Future Prospects. In: Ramparkash (ed.). Adv. Forestry Res. in India. Dehradum: International Book Distributors 4:149-164.

Singhal, R.M. and R.D. Sharma. 1983. Study of Organic Matter of Some Typical Soils of Doon Valley Forests. Indian J. For. 6:274-277.

Swamy, H.R. 1989. Study of Organic Productivity Nutrient Cycling and Small Watershed Hydrology in Natural Forests and in Monoculture Plantations in Chikamagalur District, Karnataka. Final report. Sri Jagadguru Chandrashekara Bharati Memorial College, Sringeri.

Toky, O.P. and P.S. Ramakrishnan. 1982. Secondary Succession Subsequent to Slash and Burn Agriculture (Jhum) at Higher Evaluations of Meghalaya in North East India. I. Species Diversity, Biomass and Litter Production. In: Ramakrishnan, P.S. (ed.). Ecological Implications of Jhum Cultivation on the Ecosystem Functions of Subtropical Humid Forest Stands. MAB Project Report Vol. 1. Department of Botany, North East Hill University, Shillong. pp.141-157.

Yadava, P.S. 1986. Ecological Studies on Forest Ecosystem of Manipur. Final technical report. Action oriented Himalayan Ecodevelopment Research Project. Department of Life Sciences, Manipur University, Imphal.

Yoda, K. 1968. A Preliminary Survey of the Forest Vegetation of Eastern Nepal. III. Plant Biomass in the Sample Plots Chosen from Different Vegetation Zones. J. Coll. Arts Sci. Chiba University. 5:277-302, quoted in: Cannell, M.G.R. 1982. World Forest Biomass and Primary Productivity Data. London: Academic Press. 


\section{REFERENCES}

Ahuja, D.R. 1991. Estimating Regional Anthropogenic Emissions of Greenhouse Gases. In Khoshoo, T.N. and M. Sharma (ed), Indian Geosphere-Biosphere. New Delhi: Har-Anand publications.

Andrasko, K. 1990. Climate Change and Global Forests: Current Knowledge of Potential Effects, Adaption and Mitigation Options. FAO, Forestry Department. Rome.

Ayanaba, A., S.B. Truckwell and D.S. Jenkinson. 1976. The Effects of Clearing and Cropping on the Organic Reserves and Biomass of Tropical Forest Soils. Soil Biol. Biochem, 8:519525.

Brown, S. and A.E. Lugo. 1991. Biomass of Tropical Forests of South and South-east Asia. Can. J. For. Res. 21:111-117.

Central Forestry Commission. 1981. India's Forests 1980. Department of Agriculture and Cooperation. Ministry of Agriculture, New Delhi.

Flint, E.P. and J.F. Richards. 1991. Historical Analysis of Changes in Land Use and Carbon Stock of Vegetation in South and South-east Asia. Can J. For. Res. 21:91-110.

Forest Reserch Institute (FRI). 1970. Indian Forest Utilization, Vol. 1. Manager of Publications, Delhi.

Hall, D.O., H.E. Mynick and R.H. Williams. 1991. Cooling the Greenhouse with Bioenergy. Nature 353:11-12.

Hao, W.M., M.H. Liu and P.J. Crutzen. 1990. Estimates of Annual and Regional Release of $\mathrm{CO}_{2}$ and Other Trace Gases to the Atmosphere from Fires in the Tropics. In Goldammer J.G. (ed), Fire in the Tropical Biota, Ecological Studies. Berlin: Springer-Verlag.

Houghton, R.A. 1990. The Future Role of Tropical Forest in Affecting the Carbon Dioxide Concentration of Atmosphere. Ambio 19:204-209.

Houghton, R.A. 1991. Releases of Carbon to the Atmosphere from Degradation of Forests in Tropical Asia. Can J. For. Res. 21:132-142.

Lashof, D. and D. Tirpak. 1989. Policy Options for Stabilizing Global Climate. A draft report to Congress. United States Environmental Protection Agency, Washington, D.C. 
Makundi, W., J. Sathaye and A. Ketoff. 1991. COPATH: A Spreadsheet Model for Estimating Carbon Flows Associated with Tropical Forest Use. Lawrence Berkeley Laboratory, Berkeley, CA.

Ministry of Environment and Forests. 1987. The State of Forest Report. Forest Survey of India. Dehra Dun.

Ministry of Environment and Forests. 1989. The State of Forest Report. Forest Survey of India. Dehra Dun.

Ministry of Environment and Forests. 1989a. Developing India's Wastelands. Government of India, New Delhi.

Myers, N. 1989. Deforestation Rates in Tropical Forest and their Climatic Implications. Friends of the Earth, London.

Ravindranath, N.H., H.I. Somashekhar, R. Shailaja, C.K. Parthasarathy and K.S. Jagadish. 1992. Study of Tree Plantations Resource in a Semi-arid Region of Karnataka. Accepted for Publication in Energy Environment Monitor.

Reddy, A.K.N. and B.S. Reddy. 1983. Energy in a Stratified Society: A Case Study of Firewood in Bangalore. Eco. and Poli. Weekly XVII: 1757-1770.

Tiwari, A.K. and J.S. Singh. 1987. Analysis of Forest Land Use and Vegetation in a Part of Central Himalaya, Using Aerial Photographs. Environ. Conserv. 144:233-244. 
PART 2: CHINA

FOREST-RELATED $\mathrm{CO}_{2}$ EMISSIONS IN CHINA: CURRENT ESTIMATES AND LONG-TERM FORECAST

$X u$ Deying

Research Institute of Forestry

Chinese Academy of Forestry

Beijing, China

August 1992 


\begin{abstract}
Despite its extensive forested areas, China has largely been omitted from discussions of deforestation and global climate change, because most of her forests are non-tropical. However, the social-economic factors which drive deforestation in the tropical regions are also active in China. In an effort to study the role of Chinese forests in global climate change, this paper presents information on the current state of China's forests, identifying the types of forests in China, describing the country's forest management policies and calculating recent rates of deforestation and afforestation. This study estimates that China's forests emitted 73.7 million tonnes of carbon in 1988. However, carbon uptake from forests was far higher that year, leading to a net uptake of 32.7 million tonnes. Six long-term scenarios for forest-related $\mathrm{CO}_{2}$ flux in China are presented in intervals up to the year 2050. Each scenario is based on different assumptions about certain key parameters (e.g., annual increases in afforested area, etc.) affecting China's forestry sector. The final section identifies opportunities for improving and expanding upon this research, which include refining the conversion factors and estimating emissions of methane and nitrous oxides associated with forest activities.
\end{abstract}




\section{INTRODUCTION}

China has a huge population and relatively limited forested areas. As of 1990, China's population totalled 1.13 billion persons -- a figure which currently is increasing at a rate of 1.47 percent per year. The land area covers 9.6 million square kilometers $\left(\mathrm{km}^{2}\right), 13$ percent of which is occupied by forests. Of the remaining area, arable lands account for 10 percent, grassland for 33 percent, watershed area for 2 percent, semi-arid land for 31 percent and other areas, such as cities, roads, coral reefs, etc., for the remaining 11 percent (National Statistics Bureau 1989).

On a national level, the forests play a crucial role in satisfying the country's demand for wood and other forest products. Chinese demand for wood has witnessed rapid growth due to the pressures of economic development and a rising population. The annual consumption of wood between 1984 and 1988 exceeded the net forest growth by about 20 million cubic meters $\left(\mathrm{m}^{2}\right)$. In order to meet this increasing demand, China initiated a large-scale afforestation program in the middle of the century. As of 1990, China had approximately 30.7 million hectares (ha) of planted forests, the largest area of planted forests for any country in the world. But as mentioned above, despite the impressive afforestation efforts, the consumption of forest resources has continued to out-pace forest growth.

From an international perspective, changes in China's forest cover are important because of their impact on the levels of $\mathrm{CO}_{2}$ emitted into the atmosphere. Hence, forest-related activities taking place on the national scale have implications for the global environment.

This paper provides an overview on the current state of China's forests, identifying the types of forests in China, who controls them and recent rates of deforestation and afforestation. It then provides estimates of current forest-related $\mathrm{CO}_{2}$ emissions in China and presents six longterm scenarios for $\mathrm{CO}_{2}$ in China through the year 2050 .

\section{FOREST ZONES}

China's vast land area, which reaches from the cold temperate zone to the tropical zone, encompasses many forest types and an abundance of species. Due to the organization of the biophysical data, this study dis-aggregates China's woodlands into six forest zones. In general, this zonal breakdown corresponds with differences in the types of forests located throughout the country. The zoning allows for the use of forest inventory data drawn from studies conducted at the provincial level. The distribution of the six forest zones is shown in Figure 1, as obtained from the National Statistics Bureau, 1989.

1 The figures on forested areas in the following section include Taiwan. The estimates of $\mathrm{CO}_{2}$ emissions do not include Taiwan or the area beyond the control line of Tibet due to insufficient data. If the Taiwan and Tibet figures are excluded, China's forested area equals $1: 9.5$ million hectares and covers 12.4 percent of the national land area. If these two regions are included, the total forest area adds up to 124.6 million hectares which is 12.98 percent of the combined area. 

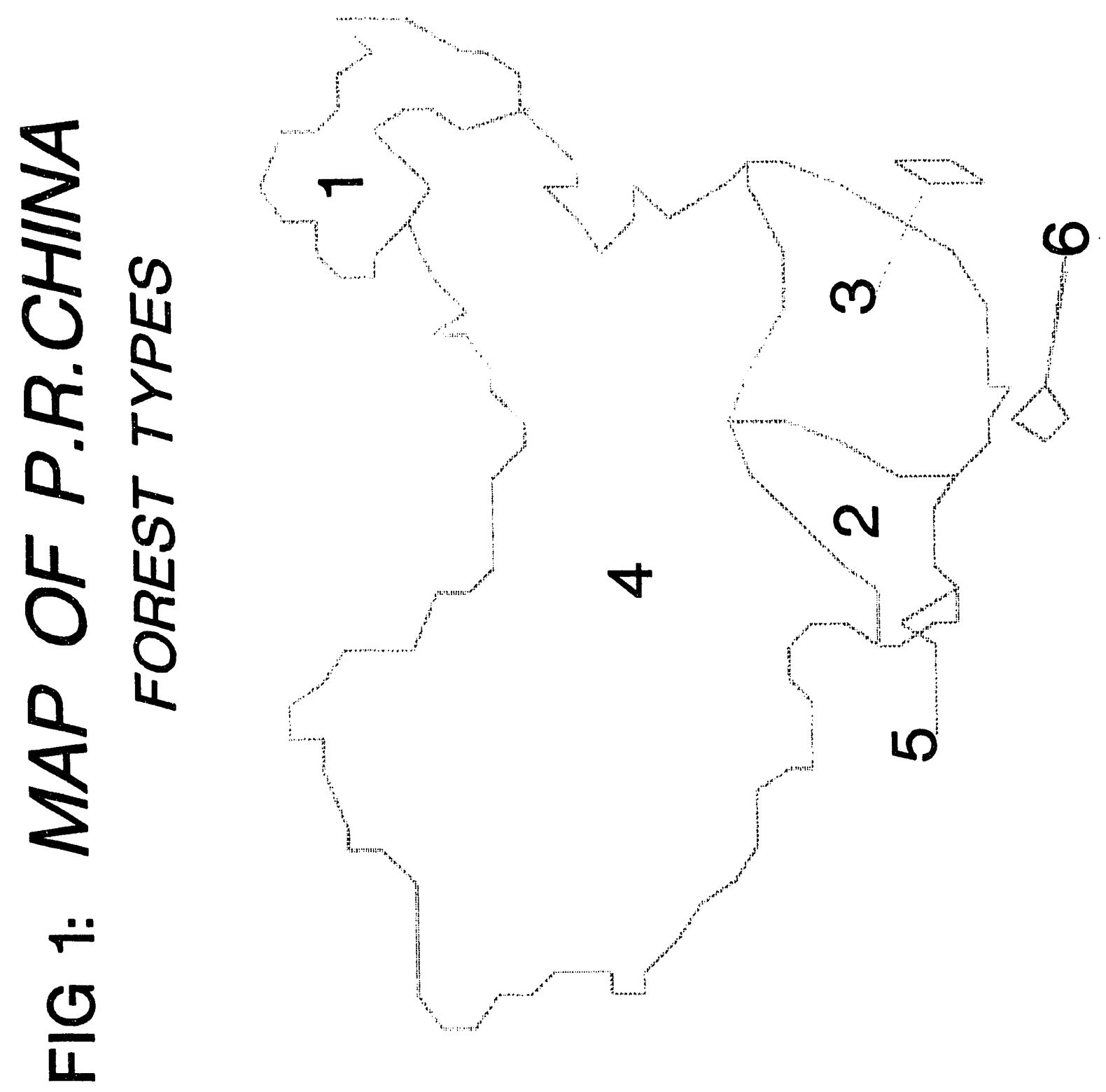

2-3 


\subsection{The temperate forest zone (Zone 1, Figure 1)}

The temperate forest zone, located in north-eastern China, includes forests located in the cool temperate zone and the temperate zone. The area is characterized by temperatures averaging about $0^{\circ} \mathrm{C}$ throughout the year and $15-20^{\circ} \mathrm{C}$ during the growing season. This zone receives about 350-1000 mm. of rainfall annually. Temperate forests covered 35.68 million ha in 1988, comprising 30 percent of the country's total forest area. The main species are larch (Larix gmelini, Larix olgensis), pine (Pinus koraiensis, $P$. sylvestris var. mongolica), and birch (Betula fruticosa and $B$. ermanii). While this district still dominates all forest production in China, production in this zone has dropped in recent years because the mature forest area has been declining by about $40,000 \mathrm{ha} / \mathrm{yr}$. The harvested timber volume averaged $87.6 \mathrm{mi} . \mathrm{m}^{3} / \mathrm{yr}$ during the past five years.

\subsection{The west sub-zone of the subtropical forest (Zone 2, Figure 1)}

Most of the subtropical areas in the world are dry lands and deserts. In the case of China, however, monsoons from the Pacific and Indian Oceans make its subtropical area a productive forest zone. The subtropical zone is divided into two sub-zones differentiated by floral species distribution. The west sub-zone has an average temperature of $10-20^{\circ} \mathrm{C}$ and an annual precipitation of 1000-1500 mm. This sub-zone includes provinces in the southwest (i.e., Yunnan, Sichuan, Guizhou, etc.). Although this zone has only 20.2 million ha of forested area, it possesses the largest volume of mature forests $\left(1765\right.$ million $\left.\mathrm{m}^{3}\right)$ in the country due to its out-ofthe-way location. The main species are pines (Pinus yunnanensis, Pinus kesya var. langbianensis) and various species of Lauraceae and Faguceae.

\subsection{The east sub-zone of the subtropical forest (Zone 3, Figure 1)}

This zone is located in China's southern district, which encompasses nine provinces to the east of the Sichuan Basin and to the south of the Yangchi River. The average temperature is 10-20 $\mathrm{C}$ and has an annual precipitation of $1000-2000 \mathrm{~mm}$. The main tree species are Chinese Fir (Cunninghamia lanceolata), pine (Pinus massoniona) and abundant species of Lauraceae and Faguceae. This forest area covers $\mathbf{4 2 . 7 6}$ million ha, of which 50 percent is occupied by Pinus massoniana and 30 percent by Cunninghamia. As shown in Table 1, this forest type has become the main source of timber, with a harvested area which is more than 3 times that of the temperate zone, which is the second largest harvested forest type.

\subsection{The warm temperate forest zone (Zone 4, Figure 1)}

This zone encompasses a vast area, from Liaotong Peninsula in the east to Xing jiang province in the west and from Inner Mongolia in the north to the Yangchi River in the south. It includes plateau provinces, such as Xizhang (Tibet) and Qinghai. This area does not represent one uniform climate zone. It is located in an arid or semi-arid region with an average annual temperature range from $5^{\circ}$ to $18^{\circ} \mathrm{C}$, and an annual precipitation between $100 \mathrm{~mm}$ and $800 \mathrm{~mm}$. Most of the forests are found in mountainous areas, which are characterized by low forest

$$
2-4
$$


productivity. The total forest area covers about 19.4 million ha. The main tree species are spruce (Picea schrenkiana, etc.) and poplars (Populus davidiana, etc.) in mountainous areas and pines (Pinus tablaeformis, etc.) and Faguceae in lower altitude regions.

\subsection{The Xishuangbanna tropical pre-montane moist forest zone (Zone 5, Figure 1)}

Xishuangbanna, located in the southern Yunnan Province, receives an average of 2000-3000 mm of rain each year, 80 percent of which falls during the rainy season. The average annual temperature is about $20-25^{\circ} \mathrm{C}$. The main tree species are Vatica xishuangbannanensis and various species of Faguceae, Dipterocarpaceae and Lauraceae. The whole district stretches across an area of 1.97 million ha, 0.57 million ha of which are forest lands. Shifting cultivation practices have led to severe deforestation in this region, as has been the case in so many other tropical areas of the world. In 1986, however, about 12 percent of the district was transferred to natural reserves, which has managed to mitigate the level of deforestation.

\subsection{The Hainan tropical pre-montane moist forest zone (Zone 6, Figure 1)}

The forests on Hainan Island do not differ significantly from those in Xishuangbanna. The climate is characterized by even more dramatic seasonal variations due to the impact of typhoons. The mean temperature is $20-25^{\circ} \mathrm{C}$, and the precipitation ranges from $1000-3000$ $\mathrm{mm} / \mathrm{yr}$. The forested area extended over 0.87 million ha of the region's total area of 3.36 million ha in 1988. The main tree species are Vatica hainannensis and various species of Faguceae, Dipterocarpaceae, Lauraceae and Euphobiaceae. Due to severe deforestation, the forested share of this island diminished from 36 percent in 1949 to 19.8 percent in 1980 . Since 1980 afforestation efforts have been expedited, raising the forested share to $25.9 \%$ as of 1988 .

\section{OWNERSHIP AND UTILIZATION OF FORESTS}

Currently, there are two major types of forest ownership in China, state-owned and collectiveowned forests. The use of forest resources is determined by national policy. Prior to 1988 each year China's Ministry of Forestry outlined a national harvest plan which permitted a certain amount of over-harvesting. In reality, however, the allowable harvest volume for overharvesting typically surpassed the planned harvest volume three- to four-fold. The Ministry instituted a new policy in 1988 obligating both state-owned and collective-owned forests to abide by national "controlling quotas", which were based on consumption levels from the previous year. These "quotas" are generally smaller than the past consumption levels. Historically the pressure to maintain production levels from the forest estate has stemmed not only from the market for forest products but also from the need to keep forest workers employed. In recent years efforts to conserve forests have been thwarted further due to rising standards of living and the lack of alternative employment opportunities for the forest workers. In the country's tropical areas (Xishuangbanna and Hainan Island), where the government has relatively little control, shifting cultivation has caused severe deforestation. As the population has grown, the area cleared by slash-and-burn methods has expanded. The total forested areas and rates of landuse change by conversion mode and forest type are shown in Table 1. 


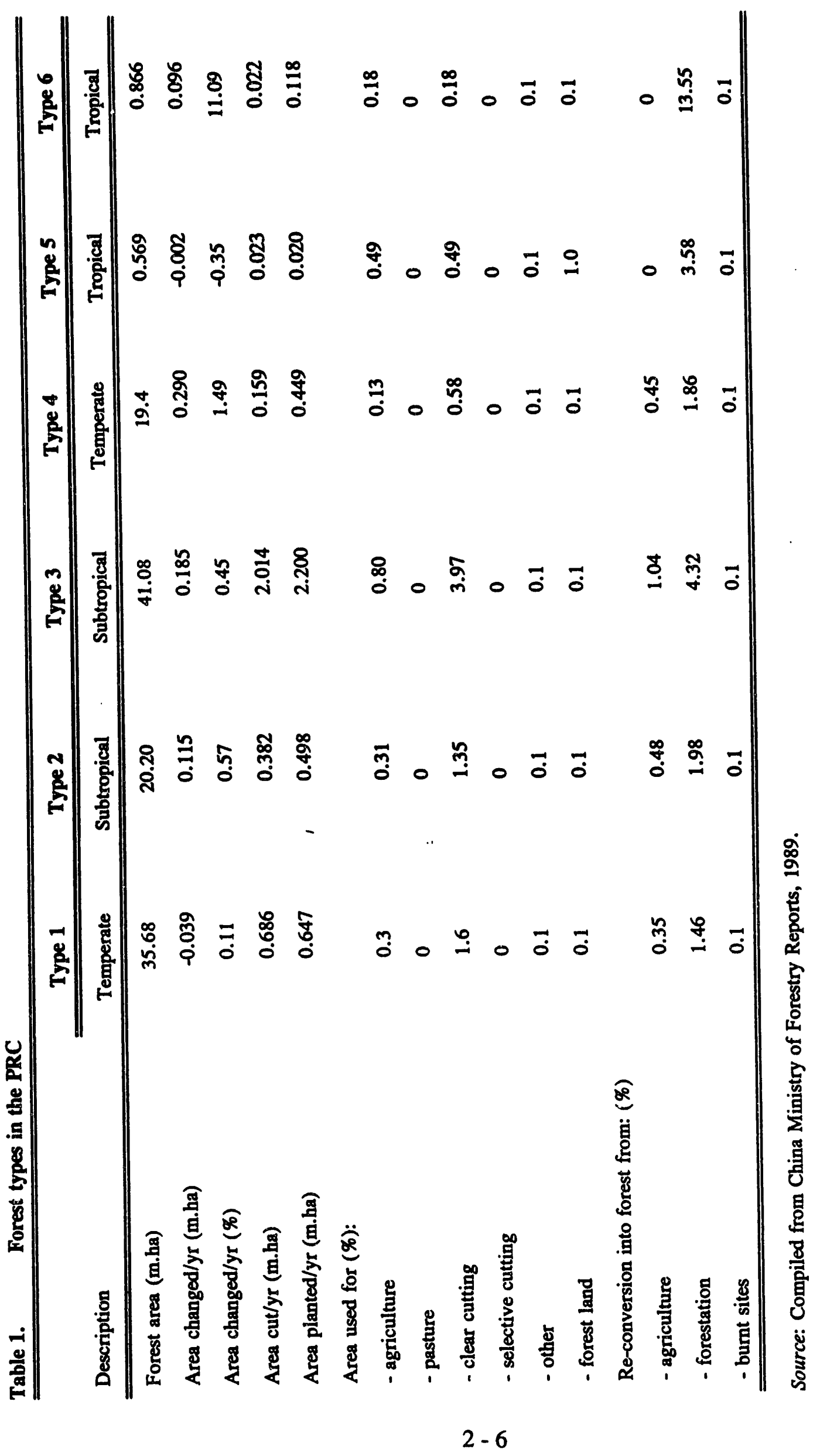


China's Ministry of Forestry has maintained reliable records on national levels of timber production and consumption. Figures for 1988 indicate that 32.5 percent of the nation's timber supply was used for fuelwood, followed by 14.2 percent for rural buildings. Consumption of forest resources averaged 344.8 million $\mathrm{m}^{3}$ per year between 1984 to 1988 , while the total stock of forest resources grew by 322.9 million $\mathrm{m}^{3}$ during the same period. Because the consumption of forest products surpassed the new forest growth, China experienced a forest stock deficit of 21.9 million $\mathrm{m}^{3}$ in 1988 (see Table 1 in China Ministry of Forestry 1989).

Relative to the size of the population, China has fairly limited forest resources. The forested area per capita of 0.11 ha and the stock volume per capita of $8 \mathrm{~m}^{3}$ per capita amount to approximately one-sixth and one-ninth of the world average respectively. Despite relatively low levels of timber consumption per capita, if the 1988 levels of timber harvesting prevail, the country will exhaust its harvestable forest resources within the next 10 years (Deying, 1991).

\section{REFORESTATION AND AFFORESTATION}

The rapid depletion of China's forest resources has been the major galvanizing force behind the nation's large-scale afforestation program. The area of planted forests in China reached 30.66 million ha by 1990, far surpassing the planted forest areas in any other nation in the world. Between 1984 and 1988, China planted 3.932 million ha of forest cover per year; over this same period, China cleared 3.287 million ha of forest land per year. Hence, there was a net annual increase of 0.645 million ha of forested area. The net increase rate accelerated after 1988. The area of newly planted young forests totalled 5.33 million ha in 1989 and 5.53 million ha in 1990. In the latter year, China also designated 3.67 million ha of closed hillsides for facilitating forest development (Gao 1990).

China has initiated a large-scale shelter-belt system in the vast temperate semi-arid zone which covers 42.4 percent of the land area. A total of 6.06 million ha of land has been mosaicked with shelter-forests, raising the share of forest cover from 4 to 5.9 percent in that region. The nation has also begun implementing a shelter-forest system in the upper reaches of the Yangchi River and another afforestation plan in Taihang Mountains.

A nationwide voluntary tree-planting campaign was initiated in 1981. About 300 million people have participated in the campaign and 1700 million trees have been planted each year since its implementation. Over the next 30 years, the Chinese Government is planning to develop 20 million ha of fast-growing timber forests located in south-east China. Eight million ha of fast-growing forests are to be established by the end of the century. Efforts to stem rates of deforestation have included the construction of a large-scale telecommunication system (initiated in 1987) which will allow for faster responses to fires in China's northern forests.

China's goal is to increase its forest area by 40 million ha by the end of the century, thereby raising the share of national land area covered by forests to 17.1 percent. The historical changes in forest cover and the targets for the planned scheme are shown in Figure 2. 


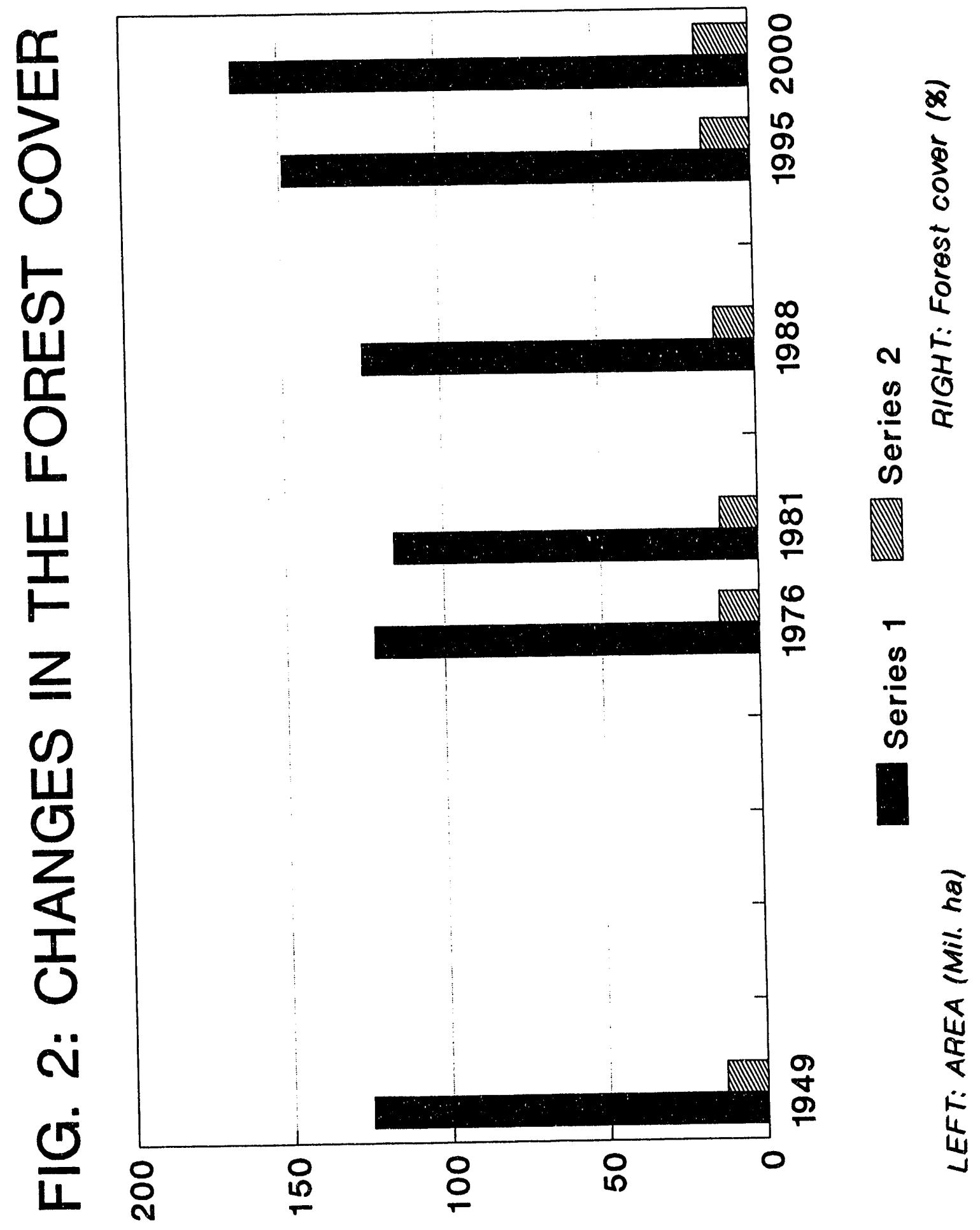

$$
\text { 2- } 8
$$




\section{MODEL AND PARAMETERS}

This study used the COPATH model (Makundi et al. 1990) to calculate carbon emissions from forest sources in China. The basic data was drawn from the forestry inventories conducted in China in 1977-81 and 1984-88 (China Ministry of Forestry 1989). Because this data lacked other information required by the model such as wood density, carbon content and conversion rates, other published literature was used to supplement the information taken from the Ministry reports. The data on forest changes were re-adjusted to fit the particular requirements of the COPATH model. In order to separate China's tropical forests from its total forested areas, recently published literature (Liang 1988; Kuang 1985) was used to calculate or estimate forest changes in Xishuangbanna and Hainan Island, China's only tropical zones. The original version of COPATH did not account for the re-conversion of agricultural and waste lands to forests, because this practice is not common in developing countries other than China. Although China converts a large area of land from forests to crop fields each year, it re-converts an even larger area of land from crop fields to forest lands. The COPATH model was revised and specifically adapted to China's particular conditions (Makundi, 1991).

The basic data on forest areas, conversion rates, biomass and wood density are presented in Tables 1-3. The data on forest areas and conversions came from the national inventory (China Ministry of Forestry 1989). There are about 255,000 permanent survey sample plots distributed across the country. The Chinese Ministry of Forestry organizes a nationwide inventory once every five years. The change in forest resources was calculated from the data collected in the last two inventories mentioned above.

Table 2. Biomass in sampled forests

\begin{tabular}{lccccc}
\hline $\begin{array}{l}\text { Dominant } \\
\text { species }\end{array}$ & $\begin{array}{c}\text { Stem } \\
\text { biomass }\end{array}$ & $\begin{array}{c}\text { Total } \\
\text { biomass }\end{array}$ & $\begin{array}{c}\text { Total/ } \\
\text { aboveground }\end{array}$ & $\begin{array}{c}\text { Aboveground/ } \\
\text { stemwood }\end{array}$ & Remark \\
\hline \hline Phoebe bourmei & 65.39 & 174.4 & 1.22 & 1.25 & Subtropic \\
Castanopis fissa & $51.0 \%$ & $100.0 \%$ & 1.38 & 1.42 & Subtropic \\
Lithocarpus glaber & $36.5 \%$ & $100.0 \%$ & 1.51 & 1.81 & Subtropic \\
Larix gmelini (1) & $66.2 \%$ & $100.0 \%$ & 1.25 & 1.21 & Temperate \\
Larix gmelini (2) & 177.4 & 249.7 & 1.31 & 1.07 & Temperate \\
Larix gmelini (3) & 206.7 & 251.1 & 1.10 & 1.10 & Temperate \\
Larix mastersiana & 87.3 & 135.2 & 1.19 & 1.30 & Temperate \\
Picea schrenkiana & 183.5 & 286.9 & 1.18 & 1.32 & Temperate \\
Tropical Forest & 202.9 & 297.0 & 1.24 & 1.18 & Tropical \\
$\begin{array}{l}\text { (21 species) } \\
\text { Cunninghamia }\end{array}$ & 97.4 & 150.7 & 1.19 & 1.29 & Subtropic \\
lanceolata & & & & & \\
\hline \hline
\end{tabular}

Note: Biomass in the unit of Tonnes/ha. Others are in "\% ".

Source: Feng et al. 1985; Liu et al. 1987; Yang 1985; Zhang 1986. 
Forest lands are not converted into pasture in China. The amount of land struck by forest fires had to be estimated, since the inventory lacked this data. Some selective cutting occurred in China's tropical regions under the government's harvesting policy; these areas were estimated based on data drawn from some unofficial publications. Biomass data came from selected articles (Feng et al. 1985; Liu et al. 1987; Yang 1985; Zhang 1986). Destructive sampling was used in the biomass studies, and the biomass ratios were calculated based on the above sources. The data on wood densities were cited from a book published by the Division of Wood Character (1981) (Table 3).

Table 3. Wood density of sampled species (tonnes $/ \mathrm{m}^{3}$ )

\begin{tabular}{lclc}
\hline \hline Tree species & Wood density & Tree species & Wood density \\
\hline \hline Abies dellzvayi & 0.41 & Cupressus funebris & 0.49 \\
Larix gmelini & 0.53 & Picea schrenkiana & 0.35 \\
Pinus koraiensi & 0.35 & Pinus masonianna & 0.45 \\
Pinus tablaeformis & 0.42 & Pinus yunnanensis & 0.51 \\
Tsuga dumosa & 0.38 & Cassia siamea & 0.59 \\
Cinnamomum camphora & 0.44 & Cyclobalanopsis glauca & 0.71 \\
Eucalyptus globulus & 0.64 & Dipterocarpus tonkinensis & 0.54 \\
Fagus longipetiolata & 0.64 & Hopea mollissima & 0.75 \\
Tectona grandis & 0.50 & & \\
\hline \hline
\end{tabular}

Source: Division of Wood Character, 1981.

The carbon content of wood was cited from Buring (1984). The soil carbon content was calculated based on limited Chinese literature (Zhang 1986; Ye \& Cai 1986; Ma 1990; Soil Survey Group 1981). The amounts of carbon released in the conversion process and during the decomposition period were estimated using data from corresponding forest types in other countries. The biomass left for decomposition in the whole country was estimated from indigenous biomass studies (Feng et al. 1985; Yang 1985; Zhang 1986; Li et al. 1987). The values of the parameters used are given in Table 4 below. 
Table 4. Values of Main Parameters used in the Model

\begin{tabular}{|c|c|c|c|c|c|c|}
\hline \multirow[t]{2}{*}{ Parameter } & \multicolumn{6}{|c|}{ Forest type } \\
\hline & 1 & 2 & 3 & 4 & 5 & 6 \\
\hline Carbon content & 0.55 & 0.52 & 0.52 & 0.55 & 0.52 & 0.52 \\
\hline Dry biomass (ton/ha) & 250 & 270 & 288 & 288 & 300 & 207 \\
\hline Overbark stemwood $\left(\mathrm{m}^{3} / \mathrm{ha}\right)$ & 142 & 218 & 96 & 151 & 300 & 280 \\
\hline Wood density (ton $\left./ \mathrm{m}^{3}\right)$ & 0.44 & 0.51 & 0.38 & 0.40 & 0.58 & 0.60 \\
\hline Ratio of above/stem biomass & 1.1 & 1.3 & 1.2 & 1.3 & 1.4 & 1.8 \\
\hline Ratio of total/above biomass & 1.1 & 1.2 & 1.2 & 1.2 & 1.4 & 1.24 \\
\hline Carbon in soil (ton/ha) & 155 & 97 & 97 & 97 & 140 & 140 \\
\hline Period of long-term use & 0.2 & 0.2 & 0.2 & 0.2 & 0.2 & 0.2 \\
\hline Period of short-term use & 15 & 15 & 15 & 15 & 15 & 15 \\
\hline Decomposition period (year) & 50 & 40 & 40 & 50 & 30 & 30 \\
\hline Annual increment (ton/yr) & 2.2 & 3.03 & 3.58 & 1.65 & 3.03 & 3.58 \\
\hline Rotation age (year) & 60 & 30 & 30 & 60 & 30 & 30 \\
\hline
\end{tabular}

Source: See text.

\section{6. $\mathrm{CO}_{2}$ EMISSIONS}

The carbon dioxide emitted and absoibed from forest-related activities were calculated using COPATH (in terms of million tonnes of carbon equivalent). In order to facilitate comparisons with tropical countries, this study presents estimates of emissions solely resulting from tropical forests in China as well as estimates of those from all of the country's forests (tropical and nontropical). Projections were made for a base year (1988) and a range of different years (1990, 1995, 2000, 2010, 2025 and 2050) to allow for comparisons with other studies (Table 5).

It is interesting to compare the patterns of emissions in different forest zones in the base year. Zone 1, which had the largest harvested area in the country and a smaller reforested area, did not have the greatest level of net emissions of all forest types. Zone 4 had the largest net increase in forested area but not the largest net uptake. This difference can be explained by the relatively low rate of biomass accumulation in zone 4. Although zones 2 and 3 have similar climates, zone 3 had the largest harvested and planted areas, whereas zone 2 had relatively small harvested and planted areas. Nonetheless the net increases in forested area were quite similar for these two zones $(0.45$ percent and 0.57 percent respectively) (Table 1$)$. In the base year, forested area declined in zone 5, but increased in zone 6 (surpassing the amount cleared by a factor of five) (Table 1). Nonetheless, zone 6 had higher net emissions than zone 5.

The carbon emissions from the use of forest resources in China totalled 74 million tonnes during 1988 (Table 5), and 62 million tonnes will be released in the future as a result of forest use in the base year. However, the COPATH model did not incorporate inherited carbon uptake from growing stock prior to the base-year. In the case of China, the total uptake was estimated by using the growth data for different regions in the country. The annual sequestration from the 





growing forests was estimated at 112 million tonnes, of which 106.4 was the inherited uptake. If one assumes that the delayed release equals the emissions from historical forest use, then the annual balance flux from China's forest sector is 24 million tonnes of carbon in 1988. Estimates derived using a simpler model ${ }^{2}$ indicate that there was a net uptake of 2.5 million tonnes of carbon in 1988. Considering the different methods used in the two modeis, the difference between these two results is quite small.

Projections of carbon emissions were made based on six different future scenarios for China. Table 6 outlines the parameters used for each of the scenarios. According to the national plan, China's forest area will increase by 40 million ha in the next 10 years. This increase would require the current growth rate of forest areas $(0.62$ million ha/year) to increase by a factor of 6.2. Scenario 3 assumes that the country is successful in achieving the above rate of increase in forested areas. In this scenario, the average growth rate averages 32 percent per year. In Scenario 2, the national plan achieves only two-thirds of its targeted increase, resulting in a growth rate of 27 percent per year. Scenario 1 assumes the national plan meets half of its set goal, thereby lowering the growth rate to 20 percent per year. Table 6 illustrates the varying assumptions used in Scenarios 4-6.

Table 7 presents total forest-related emissions and tropical forest-related emissions for China for the six different scenarios at various intervals between 1990 and 2050. The national trends are similar in all of the scenarios. In the early time frame, the net emissions do not differ significantly among scenarios. Net emissions decrease during the first few years, reaching their lowest point between 2006 and 2009.

The maximum net absorptions were about 58, 135 and 250 million tonnes of carbon in Scenarios 1,2 and 3 respectively. Net emissions then increase, leveling out near zero by the year 2030 . Increases in agricultural and other land have a minimal impact on the net emission estimates, because afforestation still increases far more rapidly than the forest clearings for agriculture and other purposes.

In the case of tropical forests, the acceleration or deceleration of current deforestation rates would lead to changes in the amount of carbon released. However, the scenarios indicate that emissions from tropical forests will remain stable over the next 60 years.

2 An earlier paper by Xu Deying (1990): Greenhouse Gas Emissions and China's Forests: A Simple Model, calculated emissions using simpler model which did not dis-aggregate the forested area by forest type but instead focused on the consumption patterns of forest resour; as as opposed to taking the COPATH model's integrated approach. 
Table 6. Scenario parameters

\begin{tabular}{llllllll}
\hline \hline \multirow{2}{*}{ Element } & \multicolumn{7}{c}{ Scenario } \\
\cline { 2 - 8 } & \multicolumn{1}{c}{1} & \multicolumn{7}{c}{ 2 } & 3 & 4 & 5 & 6 \\
\hline \hline Land growth for agriculture & 0 & 0 & 0 & 0.01 & 0.001 & 0.001 \\
Land growth for fallow & 0 & 0 & 0 & 0 & 0 & 0 \\
Land growth for afforestation & 0.2 & 0.27 & 0.32 & 0.2 & 0.2 & 0.32 \\
Land growth for select cutting & 0 & 0 & 0 & 0 & 0 & 0 \\
Land growth for other land use & 0 & 0 & 0 & 0.01 & 0.001 & 0.001 \\
\hline \hline
\end{tabular}

Table 7. Net $\mathrm{CO}^{2}$ emissions for different scenarios $\left(10^{3}\right.$ tonnes)

\begin{tabular}{|c|c|c|c|c|c|c|}
\hline \multirow[t]{2}{*}{ Scenario } & \multicolumn{6}{|c|}{ Year } \\
\hline & 1990 & 1995 & 2000 & 2010 & 2025 & 2050 \\
\hline $\begin{array}{c}1 \\
\text { Total } \\
\text { Type } 5 \\
\text { Type } 6\end{array}$ & $\begin{array}{r}22723 \\
1155 \\
1842 \\
\end{array}$ & $\begin{array}{l}4122 \\
3479 \\
6565\end{array}$ & $\begin{array}{r}-35921 \\
3914 \\
7764 \\
\end{array}$ & $\begin{array}{r}-48136 \\
2647 \\
5427 \\
-\end{array}$ & $\begin{array}{r}-2059 \\
122 \\
205\end{array}$ & $\begin{array}{r}-635 \\
21 \\
5 \\
\end{array}$ \\
\hline $\begin{array}{c}2 \\
\text { Total } \\
\text { Type } 5 \\
\text { Type } 6\end{array}$ & $\begin{array}{r}22461 \\
1154 \\
1842 \\
\end{array}$ & $\begin{array}{r}-5231 \\
3447 \\
7686\end{array}$ & $\begin{array}{r}-73219 \\
3784 \\
7686\end{array}$ & $\begin{array}{r}-124570 \\
2382 \\
5265\end{array}$ & $\begin{array}{r}-14093 \\
82 \\
181\end{array}$ & $\begin{array}{r}-899 \\
21 \\
5\end{array}$ \\
\hline $\begin{array}{c}3 \\
\text { Total } \\
\text { Type } 5 \\
\text { Type } 6\end{array}$ & $\begin{array}{r}22274 \\
1154 \\
1841 \\
\end{array}$ & $\begin{array}{r}-13269 \\
3419 \\
6528 \\
\end{array}$ & $\begin{array}{r}-112570 \\
3647 \\
7602 \\
\end{array}$ & $\begin{array}{r}-264884 \\
1957 \\
5006 \\
\end{array}$ & $\begin{array}{r}-40818 \\
-10 \\
125\end{array}$ & $\begin{array}{r}-1177 \\
21 \\
5\end{array}$ \\
\hline $\begin{array}{c}4 \\
\text { Total } \\
\text { Type } 5 \\
\text { Type } 6\end{array}$ & $\begin{array}{r}22950 \\
1158 \\
1844 \\
\end{array}$ & $\begin{array}{l}5251 \\
3494 \\
6572\end{array}$ & $\begin{array}{r}-34967 \\
3928 \\
7771 \\
\end{array}$ & $\begin{array}{r}-48093 \\
2649 \\
5428 \\
\end{array}$ & $\begin{array}{r}-2080 \\
123 \\
206\end{array}$ & $\begin{array}{r}-623 \\
22 \\
5\end{array}$ \\
\hline $\begin{array}{c}5 \\
\text { Total } \\
\text { Type } 5 \\
\text { Type } 6\end{array}$ & $\begin{array}{r}22831 \\
1156 \\
1843\end{array}$ & $\begin{array}{l}4637 \\
3486 \\
6569\end{array}$ & $\begin{array}{r}-35500 \\
3920 \\
7768\end{array}$ & $\begin{array}{r}-48113 \\
2647 \\
5427\end{array}$ & $\begin{array}{r}-2061 \\
122 \\
206\end{array}$ & $\begin{array}{r}-636 \\
21 \\
5\end{array}$ \\
\hline $\begin{array}{c}6 \\
\text { Total } \\
\text { Type } 5 \\
\text { Type } 6\end{array}$ & $\begin{array}{r}22296 \\
1154 \\
1842\end{array}$ & $\begin{array}{r}-13158 \\
3420 \\
6528\end{array}$ & $\begin{array}{r}-112499 \\
3648 \\
7602\end{array}$ & $\begin{array}{r}-246880 \\
1957 \\
5006\end{array}$ & $\begin{array}{r}-40820 \\
-10 \\
125\end{array}$ & $\begin{array}{r}-1178 \\
21 \\
5\end{array}$ \\
\hline
\end{tabular}

Note: " - " means absorption. 


\section{ECONOMIC ASPECTS}

The model indicates that a long time lag exists between the time of afforestation and that of significant carbon absorption from the newly planted trees. In addition, the impact of different rates of afforestation on carbon emissions appear to be minimal over the long term, unless the rate of deforestation and forest utilization declines substantially.

The cost of establishing, managing and harvesting seven different types of species (Eucalyptus, Poplar, Pawlonia, Cunninghamia, Larch, Pine and Locust) in China was investigated by the Office of Project Loans in 1989. It was found that the cost of establishing the forests ranges from 270 to 440 US\$/ha depending on the species and the climatic regions; the average cost is 400 US $\$ /$ ha. The managerial activities will cost a sum of approximately $350 \mathrm{US} \$ / \mathrm{ha}$ for each rotation. Assuming a carbon uptake potential of about 130 tonnes $/ \mathrm{ha} /$ rotation, this direct cost would imply an investment of about 5 US\$/ton of carbon sequestered. However, if we include the other overhead costs such as constructing forest tracks, roads and other transportation investment, the average cost jumps to $3200 \mathrm{US} \$ /$ ha per rotation, which means an investment of about 24 US $\$ /$ ton of carbon sequestered. Some broadleaf and mixed stands may entail even higher costs due to their relatively long rotations. If only the costs of establishing and managing the stands are considered, the total costs for the next 10 years would be 30 billion US\$. However, the cost structure under such a large afforestation program is different on account that some of the cost elements will be procured without monetary compensation. Past afforestation schemes in China have involved a large degree of voluntary labour force. Furthermore, the large cost outlay must be balanced by the value of the forest products such as timber and water which would be realized from the program.

\section{DISCUSSION AND FUTURE RESEARCH}

To obtain a more accurate picture of carbon emissions in China, the COPATH model need to account for both inherited emissions and uptake. The carbon flux from the simple model cited earlier differs significantly from the estimate from COPATH. The difference may rise from two sources: a) the carbon accumulated in the soil of newly planted forests, which was not explicitly incorporated into the COPATH model and/or b) differences in the assumptions about carbon emitted from disturbed soils. Some of the soil carbon data used in the calculations were cited in the literature (Wanru 1986; Xiehua 1990; Zhongje et al. 1986; "A Survey on the Forest Soils at Deqinshan Forestry Experimental Bureau" 1981). However, the data were not detailed enough to provide a full picture of soil carbon content for all the various forest types. There is still insufficient data on carbon emissions from soil disturbance. The simple model assumed that no net emissions resulted from the soil in China. As such, COPATH may have underestimated carbon uptake while the simple model may have underestimated emissions from both past deforestation as well as from soil disturbance. 
The existing carbon stock was calculated by multiplying the total forested area by the average stock volume. In carrying out this equation, however, small errors in the conversion factors used for calculating stock volume can lead to major errors in the carbon stock estimates. In addition, the use of different growth rates can lead to a wide range of projections. The use of growth data (from yield studies), for the total volume in a region can minimize the errors. These data are usually available in countri ; where inventories are conducted in regular intervals.

Present carbon emissions are the result of past and present actions (i.e., changes in forested areas, conversion rates, re-conversion rates, wood consumption, decomposition rates for different consumption modes, emission rates of disturbed soils, forest growth rates, etc.). The COPATH model does not account for emissions stemming from past activities. At the same time the uptake by growing forests from past forest use is not include in the model. A more detailed version of COPATH, which incorporates all these actions -- past and present and future -- should be developed so that a complete picture of the carbon flux can be assembled.

Although the model does not impose an upper limit on the harvestable area, in the case of China where the forested area is extremely limited and only about 25 percent of the country's total land area is available for use (Deying, Forestry Strategies in Mitigating $\mathrm{CO}_{2}$ Accurnulation, 1991), imposing such a limit in the forecast portion will be necessary. The preserit afforestation plan, which entails expanding the forested share of the total land area to 17.1 percent by the end of the century seems feasible. While the planned increase in forested area may continue until 2020, it is unlikely to prevail beyond that time due to limitations on available land area.

In the future, estimates of the other greenhouse gases such as methane and nitrous oxide should be incorporated in the COPATH model.

\section{ACKNOWLEDGEMENTS}

Acknowledgements are extended to the United States Environmental Protection Agency for their financial support and to Dr. Jayant Sathaye and Dr. Willy Makundi of the Lawrence Berkeley Laboratory for organizing and coordinating the F-7 Research Network and for their helpful insights at the Berkeley Workshop. The author is grateful to Dr. Changshen $\mathrm{Li}$ of The Bruce Company, Washington D.C., and Dr. Gao Liu of The Department of Forestry and Resource Management of the University of California at Berkeley for their critical review of this report. 


\section{REFERENCES}

Buring, P. 1984. Organic Carbon in Soil of the World. In G.M. Woodwell (ed), The Role of Terrestrial Vegetation in the Global Carbon Cycle. New York: Wiley pp. 91-109.

China Ministry of Forestry. 1989. Statistics of Forest Resources of China. Beijing.

Chunjiang, L. et al. 1987. A Study on the Biomass of Pinus Tablaeformis. Journal of Beijing Forestry University 9(1).

Deying, X. 1991. Forestry Strategies in Mitigating $\mathrm{CO}_{2}$ Accumulation. Proceedings of National Conference on Atmospheric Changes and Environmental Problems. Paper \#116. Beijing.

Deying, X. 1991. Global Atmospheric $\mathrm{CO}_{2}$ Emissions and the World Forests. Proceedings of National Conference on Atmospheric Changes and Environmental Problems. Paper \#107. Beijing.

Deying, X. 1991. Greenhouse Gas Emissions and China's Forests: a Simple Model. Research Institute of Forestry, Chinese Academy of Forestry, Beijing, China.

Division of Wood Character. 1981. Handbook of Physical Properties of Woods of Chinese Tree Species. Beijing: Forestry Press.

Gao, D. 1990. The Government Report on the Development of Forestry in China. Renming Ribao, People's Daily. 27 December 1990.

Kuang B. C. 1985. The Conservation and Development of Tropical Forests in China. Forest Science and Technology in the Tropics. 4: 41-48.

Liang D. J. 1988. The Natural Reserve of Xiishuangbanna. Tropical Geography 1(2):166-171.

Ling, F. et al. 1985. A Study on Biomass of Three Types of Primary Larch Stands. Forestry Science 21(1).

Liu C.J. et al. 1987. A Study of the Biomass of Pinus Tableaformis. Journal of Beijing Forestry University 9(1).

Ma X. H. 1990. Soil Physical Properties and Water Content under Pinus massoniana and Cunninghamia lanceolata Plantations. Forestry Research 1:63-69

Makundi, W. et al. 1991. Description of a Spreadsheet Model for Estimation of Carbon Flows Associated with Forest Use. Lawrence Berkeley Laboratory, Berkeley, CA. LBL-30525. 
National Statistical Bureau. 1989. Yearbook of National Statistics. Beijing: National Statistics.

Soil Survey Group. 1981. A Survey of the Forest Soils at Daqingshan Forestry Experimental Bureau. Sience and Technology at Qingshan Experimental Base (unofficial publication) 1:65121.

Wanru, Z. 1986. Forest Soils in China. Beijing: Science Press.

Xiehua, M. 1990. Soil Physical Properties and Water Content under Pinus Massoniana and Cunninghamia Lanceolata Plantations. Forestry Research 1:63-69.

Xue Y. Z. and Zu Y. K. 1990. A Report of the Timber Consumption and its Allocation in 1988. Forest Resource Management. 1:4-5.

Yang, Y. 1985. Biomass of Some Tropical Forest Stands. Science and Technology of Tropical Forestry 2.

Ye, Z. J. \& Cai X. C. 1986. Forest Soils in Zhejiang Province, Hangzhou. Zhejing Science and Technology Press.

Zhang W. R. 1986. Forest Soil in China. Beijing Science Press.

Zhongje, Y. et al. 1986. Forest Soils in Zhejiang Province. Hanzhou: Zhejiang Science and Technology Press. 


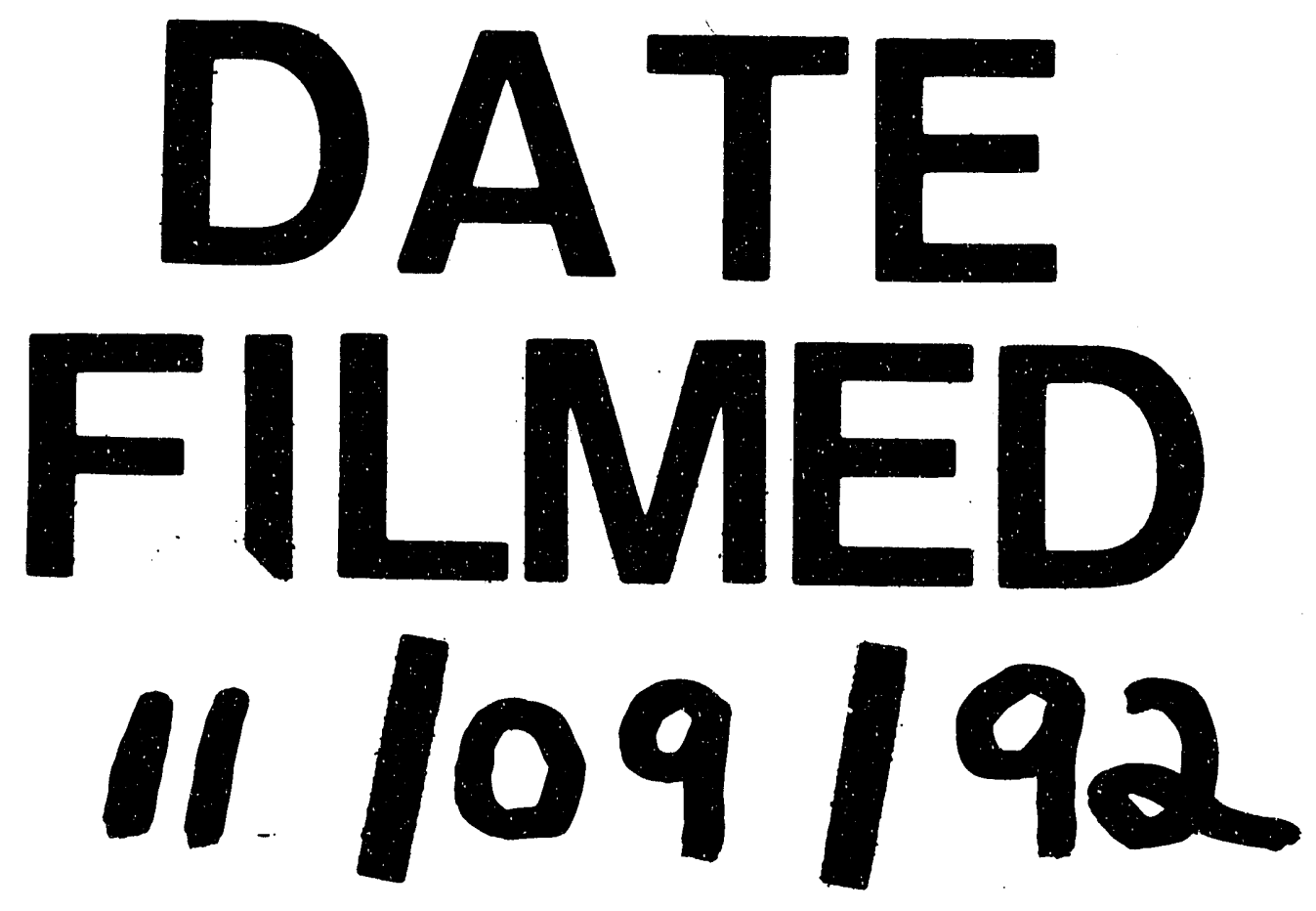


